



\section{Panduan Audit Investigatif Korupsi di Bidang Kehutanan}

Dwi Hartoyo 
(c) 2011 Center for International Forestry Research

Hak cipta dilindungi oleh Undang-Undang

Dicetak di Indonesia

ISBN 978-602-8693-26-4

Hartoyo, D. 2011 Panduan audit investigatif korupsi di bidang kehutanan. CIFOR, Bogor, Indonesia.

Foto sampul depan oleh Yayan Indriatmoko

Tata letak oleh Gun gun Rakayana Y.

\author{
CIFOR \\ JI. CIFOR, Situ Gede \\ Bogor Barat 16115 \\ Indonesia \\ T $\quad+62(251) 8622-622$ \\ F $\quad+62(251) 8622-100$ \\ E cifor@cgiar.org
}

\title{
www.cifor.cgiar.org
}

Pandangan yang diungkapkan dalam buku ini berasal dari penulis dan bukan berarti merupakan pandangan dari CIFOR, lembaga asal penulis atau penyandang dana penerbitan buku ini. 


\section{Daftar Isi}

Daftar Singkatan $\quad$ iv

Pengantar v v

Ucapan Terima Kasih vi

1. Pendahuluan 1

1.1. Kerusakan Hutan, Kejahatan Kehutanan, Korupsi dan Pencucian Uang 1

1.2. Korupsi dan Kerusakan Hutan 5

1.2.1. Korupsi yang Berkaitan dengan Pemberian Hak dan Izin yang Berkaitan dengan Bidang Kehutanan 6

1.2.2. Korupsi yang Berkaitan dengan Pengawasan Kegiatan Usaha Kehutanan 7

1.2.3. Korupsi yang Berkaitan dengan Pemberian Hak dan Izin serta Pengawasan Kegiatan Usaha Berskala Besar di Bidang Kehutanan 8

1.3. Korupsi di Bidang Kehutanan sebagai Tindak Pidana Asal Pencucian Uang 9

\section{Pelaksanaan Audit Investigatif terhadap Indikasi Korupsi dalam}

Bidang Kehutanan 13

2.1. Audit Investigatif terhadap Indikasi Korupsi dalam Bidang Kehutanan 13

2.1.1. Pengumpulan Data dan Informasi serta Analisis Adanya Indikasi Korupsi 18

2.1.2. Pengembangan Hipotesis Kecurangan atau Kejahatan dan Perencanaan Audit

2.1.3 Pelaksanaan Audit 30

2.1.4 Penyusunan Laporan Hasil Audit 37

2.2. Penelusuran Aliran Dana Hasil Kejahatan 38

\section{Referensi}

\section{Lampiran}

1. Audit Investigatif: Kasus Hipotetik Korupsi di Bidang Kehutanan

2. Pedoman Pelaksanaan Observasi Lapangan untuk Membuktikan Adanya Deforestasi atau Degradasi

3. Contoh Prosedur Audit Investigatif

4. Bentuk-Bentuk Tindak Pidana Kehutanan dan Ancaman Pidananya sesuai Undang-Undang Nomor 41 Tahun 1999 tentang Kehutanan

5. Bentuk-Bentuk Tindak Pidana Korupsi dan Ancaman Pidananya sesuai Undang-Undang Nomor 31 Tahun 1999 Sebagaimana Telah Diperbarui dengan Undang-Undang Nomor 20 Tahun 2001 tentang Pemberantasan Tindak Pidana Korupsi

6. Hasil Tindak Pidana dan Bentuk-bentuk Tindak Pidana Pencucian Uang dan Ancaman Pidananya sesuai Undang-Undang Nomor 8 Tahun 2010 tentang Pencegahan dan Pemberantasan Tindak Pidana Pencucian Uang 


\title{
Daftar Singkatan
}

\author{
DR Dana Reboisasi \\ IPK Izin Pemanfaatan Kayu \\ IUPHHK I I In Usaha Pemanfaatan Hasil Hutan Kayu \\ IUIPHK Izin Usaha Industri Primer Hasil Hutan \\ PSDH Provisi Sumber Daya Hutan \\ TPK Tindak Pidana Korupsi \\ TPPU Tindak Pidana Pencucian Uang
}




\section{Pengantar}

Audit atau pemeriksaan investigatif adalah suatu bentuk audit atau pemeriksaan yang bertujuan untuk mengidentifikasi dan mengungkap kecurangan atau kejahatan dengan menggunakan pendekatan, prosedur dan teknik-teknik yang umumnya digunakan dalam suatu penyelidikan atau penyidikan terhadap suatu kejahatan.

Audit investigatif yang dimaksudkan pada buku ini merupakan bagian dari skema Penegakan Hukum Terpadu (Integrated Law Enforcement Approach - ILEA) yang dikembangkan oleh CIFOR untuk menelusuri dan mengungkap indikasi korupsi dalam pengelolaan kehutanan dan memberikan informasi mengenai besaran kerugian negara yang diakibatkan oleh kejahatan tersebut.

Panduan audit investigatif ini disusun sebagai bagian dari upaya untuk mendorong keterpaduan pada tingkatan teknis operasional dalam aspek pemberantasan korupsi, pencucian uang dan kejahatan kehutanan. Panduan ini disusun agar audit investigatif dapat dilaksanakan dengan baik dan hasilnya sesuai dengan kualifikasi yang dibutuhkan penyelidik dan penyidik untuk melaksanakan penyelidikan dan penyidikan korupsi, pencucian uang dan kejahatan dalam bidang kehutanan.

Panduan audit investigatif ini ditulis terutama untuk memberikan pedoman kepada para Auditor, baik di lembaga pemerintahan maupun non-pemerintahan, untuk merencanakan, melaksanakan serta menyusun laporan audit investigatif dalam rangka mengungkapkan adanya korupsi, pencucian uang dan kejahatan yang berkaitan dengan bidang kehutanan.

Fokus utama panduan ini adalah untuk pengungkapan korupsi dalam bidang kehutanan. Namun demikian, karena adanya keterkaitan antara korupsi dengan pencucian uang dan kejahatan kehutanan, pada bagian-bagian tertentu yang relevan, juga akan diungkapkan hal-hal yang berkaitan dengan pencucian uang dan kejahatan di bidang kehutanan.

Panduan ini terdiri dari dua bagian, pada bagian pertama menguraikan bagaimana kerusakan hutan, kejahatan kehutanan, korupsi dan pencucian uang saling berkaitan. Pada bagian berikutnya dibahas bagaimana melaksanakan audit investigatif terhadap indikasi korupsi dan menelusuri aliran dana hasil kejahatan di bidang kehutanan. 


\section{Ucapan Terima Kasih}

Penulisan panduan bisa terlaksana berkat semangat dan keterlibatan banyak pihak. Kami mengucapkan terima kasih kepada Komisi Pemberantasan Korupsi (KPK), Pusat Pelaporan dan Analisis Transaksi Keuangan (PPATK) dan Badan Pemeriksa Keuangan (BPK) yang telah membagi pengalaman dan memberi masukan dalam penyempurnaan naskah panduan ini.

Terima kasih juga kami sampaikan kepada para partner kami Jaringan kerja Penyelamat Hutan Riau (Jikalahari) dan Institut Hukum dan Sumber Daya Alam (IHSA) Kalimantan Timur yang telah memberikan kontribusi yang sangat berarti dalam mendukung pengembangan konsep Integrated Law Enforcement Approach (ILEA).

Ucapan terima kasih juga kami tujukan kepada Bapak Bambang Setiono dalam keterlibatannya pada studi ini.

Kami menyadari bahwa perjuangan untuk melawan pembalakan liar, korupsi dan pencucian uang masih panjang. Kami berharap bahwa adanya panduan ini bisa memberi semangat baru bagi para pihak terkait untuk terus bekerja dan membenahi benang kusut dalam penegakan hukum terkait kejahatan kehutanan, korupsi dan pencucian uang di Indonesia.

Panduan ini dapat diterbitkan dengan dukungan dana dari Kementerian Luar Negeri, pemerintah Norwegia. 


\section{Bagian Pertama \\ Pendahuluan}

\section{$1.1 \quad$ Kerusakan Hutan, Kejahatan Kehutanan, Korupsi dan Pencucian Uang}

Kerusakan hutan

\begin{abstract}
Hutan dapat mengalami kerusakan. Kerusakan hutan dapat terjadi karena adanya deforestasi yaitu perubahan tutupan hutan karena berkurangnya mahkota pepohonan sampai tingkatan tertentu atau adanya degradasi yaitu perubahan tingkatan hutan yang secara negatif mempengaruhi keadaan atau kondisi hutan dan, khususnya, menurunkan kapasitas produksi hutan'.
\end{abstract}

Kerusakan hutan mengakibatkan terjadinya penurunan fungsi ekologis hutan secara signifikan. Kerusakan hutan antara lain dapat merusak fungsi ekologis hutan dalam menyimpan dan mengeluarkan air bersih secara teratur yang akan mengurangi risiko banjir dan kekeringan. Kerusakan hutan juga merusak tingkat kelembaban udara di sekitar hutan dari transpirasi atau penguapan dari vegetasi yang ada yang dapat mendorong terbentuknya awan hujan. Kerusakan hutan juga mengurangi kemampuan vegetasi di hutan untuk menyerap dan menyimpan senyawa karbon yang dapat mengurangi kemungkinan terjadinya perubahan iklim global.

1 Terminologi deforestasi dan degradasi ini mengacu kepada definisi Food and Agriculture Organization of the United Nations (FAO) sebagaimana dimuat di dalam Global Forest Resources Assessment 2000. Untuk definisi deforestasi, batasan menurut FAO adalah berkurangnya mahkota pepohonan sampai kurang dari 10\%. Namun demikian penggunaan terminologi deforestasi di dalam panduan ini lebih mengarah kepada pengertian yang umum dan tidak dibatasi oleh persentase pengurangan mahkota pepohonan dalam tingkatan tertentu. 


\section{Deforestasi di Tujuh Pulau Besar di Indonesia tahun 2000-2005 Departemen Kehutanan}

\begin{tabular}{lrrrrrrrr}
\hline Tahun & Sumatera & Kalimantan & Sulawesi & Maluku & Papua & Jawa & $\begin{array}{c}\text { Balidan } \\
\text { Nusa } \\
\text { Tenggara }\end{array}$ & Total \\
\hline 2000-2001 & 259.500 & 212.000 & 154.000 & 20.000 & 147.200 & 118.300 & 107.200 & 1.018 .200 \\
$2001-2002$ & 202.600 & 129.700 & 150.400 & 41.400 & 160.500 & 142.100 & 99.600 & 926.300 \\
$2002-2003$ & 339.000 & 480.400 & 385.800 & 132.400 & 140.800 & 343.400 & 84.300 & 1.906 .100 \\
$2003-2004$ & 208.700 & 173.300 & 41.500 & 10.600 & 100.800 & 71.700 & 28.100 & 634.700 \\
$2004-2005$ & 335.700 & 234.700 & 134.600 & 10.500 & 169.100 & 37.300 & 40.600 & 962.500 \\
Total & $\mathbf{1 . 3 4 5 . 5 0 0}$ & $\mathbf{1 . 2 3 0 . 1 0 0}$ & $\mathbf{8 6 6 . 3 0 0}$ & $\mathbf{2 1 4 . 9 0 0}$ & $\mathbf{7 1 8 . 4 0 0}$ & $\mathbf{7 1 2 . 8 0 0}$ & $\mathbf{3 5 9 . 8 0 0}$ & $\mathbf{5 . 4 4 7 . 8 0 0}$ \\
\hline Rata-Rata & $\mathbf{2 6 9 . 1 0 0}$ & $\mathbf{2 4 6 . 0 2 0}$ & $\mathbf{1 7 3 . 2 6 0}$ & $\mathbf{4 2 . 9 8 0}$ & $\mathbf{1 4 3 . 6 8 0}$ & $\mathbf{1 4 2 . 5 6 0}$ & $\mathbf{7 1 . 9 6 0}$ & $\mathbf{1 . 0 8 9 . 5 6 0}$ \\
\hline
\end{tabular}

Sumber: Eksekutif Data Strategis Kehutanan tahun 2007, Badan Planologi Kehutanan, Departemen Kehutanan.

\begin{tabular}{|c|c|}
\hline & $\begin{array}{l}\text { Kerusakan hutan dapat terjadi karena peristiwa alam, } \\
\text { seperti kebakaran hutan, atau karena kegiatan yang } \\
\text { dikendalikan pemerintah, seperti pengalihan status } \\
\text { dan fungsi hutan serta pengusahaan hutan, atau } \\
\text { karena adanya kejahatan di bidang kehutanan, seperti } \\
\text { pembalakan liar. }\end{array}$ \\
\hline \multirow[t]{3}{*}{$\begin{array}{l}\text { Kerusakan hutan } \\
\text { dan kejahatan } \\
\text { kehutanan }\end{array}$} & $\begin{array}{l}\text { Berdasarkan data yang diperoleh dari Departemen } \\
\text { Kehutanan tingkat kerusakan hutan di Indonesia pada } \\
\text { periode tahun 1985-1997 adalah 1,87 juta hektar per } \\
\text { tahun dan pada periode tahun 1997-2000 adalah 2,83 } \\
\text { juta hektar per tahun. Sementara itu, data lain yang } \\
\text { disajikan oleh Departemen Kehutanan menunjukkan } \\
\text { bahwa rata-rata kerusakan hutan di tujuh pulau besar } \\
\text { di Indonesia pada periode tahun 2000-2005 adalah } \\
\text { 1.089.560 hektar per tahun. }\end{array}$ \\
\hline & $\begin{array}{l}\text { Dalam pengertian yang sempit pembalakan liar adalah } \\
\text { kegiatan menebang pohon atau memanen atau } \\
\text { memungut hasil hutan di dalam hutan tanpa memiliki } \\
\text { hak atau izin dari pejabat yang berwenang. }\end{array}$ \\
\hline & $\begin{array}{l}\text { Dalam pengertian yang luas, pembalakan liar juga } \\
\text { dilakukan oleh mereka yang memiliki hak atau izin } \\
\text { dari pejabat yang berwenang tetapi melaksanakan } \\
\text { penebangan atau pemanenan atau pemungutan hasil } \\
\text { hutan tanpa mengindahkan kaidah-kaidah pengelolaan } \\
\text { hutan yang lestari. Dalam pengertian ini, pembalakan } \\
\text { liar juga dapat terjadi pada perusahaan IUPHHK yang } \\
\text { melakukan penebangan habis atau tidak menerapkan }\end{array}$ \\
\hline
\end{tabular}


pola silvikultur dengan semestinya atau melakukan penebangan dengan luasan yang jauh melebihi rencana penebangan yang sudah disetujui pemerintah.

\section{Kejahatan \\ kehutanan dalam Undang-Undang Kehutanan}

Pembalakan liar hanya merupakan salah satu tetapi bukan satu-satunya bentuk kejahatan kehutanan. Undang-undang Nomor 41 Tahun 1999 tentang Kehutanan menjelaskan berbagai bentuk kejahatan di bidang kehutanan. Pasal 50 dan 78 undang-undang tersebut menjelaskan setidaknya terdapat 12 tindakan yang dapat diancam dengan sanksi pidana baik berupa pidana penjara maupun denda.

Undang-Undang Nomor 41 Tahun 1999 tentang Kehutanan menjelaskan bentuk kejahatan kehutanan selain pembalakan liar misalnya adalah menerima, membeli atau menjual hasil hutan yang berasal dari kawasan hutan yang diambil atau dipungut secara tidak sah atau mengangkut, menguasai atau memiliki hasil hutan yang tidak dilengkapi dengan surat keterangan sahnya hasil hutan.
Meluasnya kejahatan kehutanan seperti pembalakan liar diduga terjadi karena kejahatan tersebut dilaksanakan bersama-sama atau disertai dengan bentuk-bentuk kejahatan lainnya terutama korupsi dan pencucian uang. Korupsi melemahkan atau menghilangkan integritas dalam sistem pengelolaan hutan, terutama dalam kegiatan pengawasan, yang memungkinkan atau memudahkan pelaku kejahatan melakukan kejahatan kehutanan. Selanjutnya, pelaku kejahatan perlu menyamarkan atau menyembunyikan hasil kejahatan yang diperolehnya dan hal tersebut dilakukan melalui mekanisme pencucian uang.

Korupsi diperkirakan terjadi di hampir semua tahapan kegiatan di bidang kehutanan mulai dari pemberian izin usaha, pengawasan penebangan, pengangkutan, pengolahan, perdagangan antar pulau sampai dengan ekspor kayu dan hasil hutan lainnya.

Korupsi dan pencucian uang, secara langsung maupun tidak langsung, berkorelasi secara positif dengan kejahatan kehutanan yang mengakibatkan kerusakan hutan di Indonesia. 


Pendekatan
terintegrasi untuk
mencegah dan
memberantas
kejahatan kehutanan

Karena keterkaitannya yang sangat erat maka upaya untuk melaksanakan pencegahan dan pemberantasan kejahatan kehutanan dapat dilaksanakan secara terintegrasi dengan kegiatan pencegahan dan pemberantasan korupsi serta pencucian uang. Lebih dari itu, kegiatan pencegahan dan pemberantasan korupsi dan pencucian uang dapat dimanfaatkan sebagai pintu masuk untuk pencegahan dan pemberantasan kejahatan kehutanan.

\section{Follow the money versus follow the wood}

Penyelidikan dan penyidikan korupsi dan pencucian uang dilaksanakan dengan menggunakan pendekatan follow the money atau mengikuti aliran atau pergerakan uang dengan menggunakan berbagai teknik investigasi keuangan. Pendekatan ini berbeda dengan pendekatan follow the wood atau mengikuti aliran atau pergerakan kayu (mengikuti pihak yang dicurigai) yang pada saat ini lebih sering digunakan dalam penyelidikan dan penyidikan kejahatan kehutanan.

Pendekatan follow the money lebih memungkinkan penyelidik dan penyidik menemukan para pelaku utama yang tersembunyi yang sesungguhnya membiayai dan mendapat keuntungan lebih besar sekaligus mengendalikan kejahatan kehutanan. Pendekatan follow the money juga memungkinkan penyelidik dan penyidik menemukan aparat pemerintah yang menerima suap atau gratifikasi dan telah memberikan perlindungan atau tidak melaksanakan tugasnya sehingga kejahatan kehutanan terjadi. Selain itu, pendekatan follow the money juga memungkinkan penyelidik dan penyidik mengejar harta kekayaan yang dihasilkan dari kejahatan sekaligus menyita dan akhirnya merampas hasil kejahatan tersebut. Pendekatan follow the money ini harus lebih dikedepankan melalui pemanfaatan lembaga PPATK, mengingat hasil kejahatan merupakan titik terlemah dalam rantai kejahatan. Perampasan harta hasil kejahatan menghilangkan kesempatan kepada pelaku kejahatan atau orang lain untuk mendapatkan keuntungan dari kejahatan yang dilakukan, menggunakan harta kekayaan tersebut untuk mengulangi kejahatan yang sama atau melakukan bentuk-bentuk kejahatan yang lain.

Pendekatan terintegrasi juga berarti bahwa pencegahan dan pemberantasan korupsi dan pencucian uang di bidang kehutanan harus dilaksanakan secara terpadu 
oleh semua lembaga, baik lembaga pemerintah maupun non-pemerintah yang mempunyai kepentingan sekaligus kewenangan dalam pencegahan dan pemberantasan korupsi, pencucian uang dan kejahatan kehutanan.

Panduan audit investigatif ini disusun sebagai bagian dari upaya untuk mendorong keterpaduan pada tingkatan teknis operasional dalam aspek pemberantasan korupsi, pencucian uang dan kejahatan kehutanan. Panduan ini disusun agar audit investigatif dapat dilaksanakan dengan baik dan hasilnya sesuai dengan kualifikasi yang dibutuhkan penyelidik dan penyidik untuk melaksanakan penyelidikan dan penyidikan korupsi, pencucian uang dan kejahatan dalam bidang kehutanan.

Panduan audit investigatif ini dimaksudkan untuk memberikan pedoman kepada para auditor, baik di lembaga pemerintah maupun non-pemerintah, untuk merencanakan, melaksanakan serta menyusun laporan audit investigatif dalam rangka mengungkapkan adanya korupsi, pencucian uang dan kejahatan yang berkaitan dengan bidang kehutanan.

Fokus utama panduan ini adalah untuk memfasilitasi pengungkapan korupsi dalam bidang kehutanan. Namun demikian, karena adanya keterkaitan antara korupsi dengan pencucian uang dan kejahatan kehutanan, pada bagian-bagian tertentu yang relevan, juga akan diungkapkan hal-hal yang berkaitan dengan pencucian uang dan kejahatan di bidang kehutanan.

\section{$1.2 \quad$ Korupsi dan Kerusakan Hutan}

\section{Tipologi korupsi}

Berdasarkan analisis terhadap bentuk-bentuk korupsi yang terjadi di bidang kehutanan, sedikitnya terdapat tiga bentuk korupsi yang secara langsung berkaitan dengan kerusakan hutan dan kerusakan lingkungan di Indonesia yaitu:

1. Korupsi yang berkaitan dengan pemberian hak dan izin di bidang kehutanan;

2. Korupsi yang berkaitan dengan pengawasan kegiatan usaha kehutanan;

3. Korupsi yang berkaitan dengan pemberian hak dan izin serta pengawasan kegiatan usaha berskala besar di bidang kehutanan. 


\begin{tabular}{|c|c|}
\hline & $\begin{array}{l}\text { Selain bentuk-bentuk korupsi yang berkaitan langsung } \\
\text { dengan kerusakan hutan dan kerusakan lingkungan } \\
\text { masih terdapat bentuk-bentuk lain korupsi di bidang } \\
\text { kehutanan misalnya korupsi yang berkaitan dengan } \\
\text { penggunaan anggaran belanja pemerintah di bidang } \\
\text { kehutanan atau korupsi yang berkaitan dengan program- } \\
\text { program pendanaan dari pemerintah untuk upaya-upaya } \\
\text { konservasi hutan atau konservasi lingkungan. }\end{array}$ \\
\hline 1.2 .1 & $\begin{array}{l}\text { Korupsi yang Berkaitan dengan Pemberian } \\
\text { Hak dan Izin yang Berkaitan dengan Bidang } \\
\text { Kehutanan }\end{array}$ \\
\hline \multirow[t]{3}{*}{$\begin{array}{l}\text { Penguasaan atas } \\
\text { hutan oleh negara }\end{array}$} & $\begin{array}{l}\text { Undang Undang Dasar } 1945 \text { menyatakan bahwa bumi, } \\
\text { air, dan segala kekayaan yang terkandung di dalamnya } \\
\text { dikuasai oleh negara. Sementara itu, pasal } 4 \text { ayat (1) } \\
\text { Undang-Undang Nomor } 41 \text { Tahun } 1999 \text { tentang } \\
\text { Kehutanan antara lain menegaskan bahwa semua hutan } \\
\text { di dalam wilayah Republik Indonesia termasuk kekayaan } \\
\text { alam yang terkandung di dalamnya dikuasai oleh Negara. }\end{array}$ \\
\hline & $\begin{array}{l}\text { Negara sebagai pihak yang menguasai hutan dalam } \\
\text { hal ini diwakili oleh penyelenggara negara dan pejabat } \\
\text { negara. Pada diri penyelenggara negara dan pejabat } \\
\text { negara melekat kewenangan untuk memberikan hak-hak } \\
\text { dan izin yang berkaitan dengan bidang kehutanan. }\end{array}$ \\
\hline & $\begin{array}{l}\text { Pemberian hak dan izin mempunyai nilai ekonomis } \\
\text { karena di satu sisi hak dan izin tersebut dapat } \\
\text { memberikan keuntungan ekonomis kepada penerima } \\
\text { hak dan izin, di sisi lain hak dan izin tersebut bersifat } \\
\text { eksklusif dan terbatas. Pemberian hak bersifat eksklusif } \\
\text { karena jika suatu hak atau izin diberikan kepada suatu } \\
\text { pihak maka pihak yang lain akan kehilangan kesempatan } \\
\text { untuk mendapatkan hak atau izin yang sama. Selain } \\
\text { itu pemberian hak dan izin bersifat terbatas karena } \\
\text { terbatasnya luas kawasan hutan yang dapat dieksploitasi. } \\
\text { Akibatnya, pemberian hak dan izin oleh penyelenggara } \\
\text { negara dan pejabat negara juga menjadi bernilai } \\
\text { ekonomis. Semakin besar potensi keuntungan ekonomis } \\
\text { yang ada maka nilai ekonomis dari pemberian hak dan } \\
\text { izin yang berkaitan dengan bidang kehutanan tersebut } \\
\text { juga menjadi semakin besar. Selanjutnya, lemahnya } \\
\text { tata kelola dan adanya etiket buruk dari penyelenggara } \\
\text { negara dan pejabat negara dapat mendorong terjadinya }\end{array}$ \\
\hline
\end{tabular}


transaksi ekonomi dalam bentuk korupsi pada pemberian hak dan izin yang berkaitan dengan bidang kehutanan.

Bentuk-bentuk korupsi yang berkaitan dengan pemberian hak dan izin yang berkaitan dengan bidang kehutanan pada umumnya adalah korupsi yang berkaitan dengan penyalahgunaan kewenangan, sarana, atau kesempatan karena jabatan, kerugian negara, pemerasan atau penyuapan. Mereka yang terlibat dalam bentuk-bentuk korupsi ini adalah penyelenggara negara atau pejabat negara yang secara langsung maupun tidak langsung, baik di kalangan eksekutif maupun legislatif yang mempunyai kewenangan memberikan hak atau izin yang berkaitan dengan bidang kehutanan serta mereka yang mempunyai kepentingan terhadap perolehan suatu hak atau izin yang berkaitan dengan bidang kehutanan. Umumnya kejahatan korupsi seperti ini tidak berdiri sendiri, melainkan melibatkan pihakpihak lain, seperti bandar/pemberi modal, pialang kayu , dan politically exposed person (PEP).

\subsection{2}

\section{Korupsi yang Berkaitan dengan Pengawasan Kegiatan Usaha Kehutanan}

Pada saat ini sudah banyak ketentuan yang mengatur agar pengusahaan hutan di Indonesia dilaksanakan sesuai dengan prinsip tata kelola hutan lestari atau sustainable forest governance. Namun demikian, sejumlah laporan, baik dari lembaga pemerintah maupun non-pemerintah, menunjukkan bahwa ketentuan-ketentuan tersebut tidak dilaksanakan dengan baik.

Salah satu kelemahan yang menonjol yang menyebabkan ketentuan-ketentuan tersebut tidak dilaksanakan dengan baik adalah kelemahan dalam pengawasan. Aparat pemerintahan yang seharusnya melakukan pengawasan tidak melakukan tugasnya dengan baik karena kemampuan profesional yang rendah, penggunaan metode pengawasan yang konvensional, keterbatasan dana operasional, ketidaksesuaian antara jumlah personal dengan luasan wilayah yang diawasi atau keterlibatan dalam praktik korupsi, dan adanya aspek moralitas yang rendah dari pengawas tersebut. 
Korupsi yang berkaitan dengan pengawasan kegiatan usaha kehutanan antara lain berbentuk pemerasan oleh aparat pemerintah yang melaksanakan pengawasan terhadap para pelaku usaha atau penyuapan dan pemberian gratifikasi oleh pelaku usaha kepada aparat pemerintah yang secara langsung maupun tidak langsung melaksanakan pengawasan.

\section{2 .3}

\section{Korupsi yang Berkaitan dengan Pemberian Hak dan Izin serta Pengawasan Kegiatan Usaha Berskala Besar di Bidang Kehutanan}

Kegiatan usaha berskala besar di bidang kehutanan adalah bentuk kegiatan usaha yang umumnya dilaksanakan oleh pengusaha atau kelompok usaha yang memiliki konglomerasi dalam bidang usaha kehutanan. Mereka memiliki kegiatan usaha di beberapa wilayah di Indonesia atau memiliki kegiatan usaha yang terintegrasi mulai dari pemanenan dan pemungutan kayu, pengolahan kayu bahkan industri kehutanan seperti industri bubur kertas dan kertas (mereka memegang kendali dari bagian hulu sampai bagian hilir). Dengan skala usaha yang besar, mereka membutuhkan bahan baku yang banyak dan mereka juga menguasai hak atas kawasan hutan yang sangat luas.

Korupsi yang melibatkan pelaku usaha berskala besar di bidang kehutanan pada dasarnya tidak berbeda dengan bentuk-bentuk korupsi yang berkaitan dengan pemberian hak dan izin serta pengawasan kegiatan usaha di bidang kehutanan seperti yang sudah dijelaskan pada bagian sebelumnya. Namun demikian, korupsi yang melibatkan pelaku usaha berskala besar pada umumnya lebih terorganisir dan lebih tersembunyi. Korupsi terbentuk dari hubungan kolutif dalam rentang waktu yang panjang antara pelaku usaha dengan penyelenggara negara dan pejabat negara yang mempunyai kewenangan dalam pemberian hak dan izin atau melakukan pengawasan terhadap kegiatan usaha berskala besar di bidang kehutanan.

Hubungan yang bersifat kolusi tersebut diwariskan dari pejabat terdahulu kepada pejabat penggantinya; akibatnya praktik pertemanan kolutif tersebut sangat sulit untuk diberantas. 
Korupsi di Bidang Kehutanan sebagai Tindak Pidana Asal Pencucian Uang

Kejahatan dengan motif ekonomi
Tindak pidana korupsi, termasuk korupsi di bidang kehutanan, merupakan salah satu bentuk kejahatan dengan motif ekonomi. Pelaku kejahatan melakukan kejahatan tersebut karena didasari suatu niatan untuk memperoleh keuntungan ekonomis dari kejahatan yang dilakukannya.
Hasil kejahatan
Keuntungan ekonomis diperoleh dari harta kekayaan yang didapat dari kejahatan dan dikenal dengan istilah harta kekayaan hasil kejahatan atau harta kekayaan hasil tindak pidana atau proceeds of crime. Bentuknya bisa berupa uang, baik dalam denominasi rupiah maupun denominasi lainnya, atau benda lain yang setara dengan uang, seperti cek, bilyet giro atau cek pelawat (travelers' checks) atau berbagai bentuk benda berharga lainnya.
Pencucian

uang: Upaya menyamarkan atau menyembunyikan asal-usul hasil kejahatan
Pelaku kejahatan akan berupaya agar kejahatan yang dilakukannya tidak bisa teridentifikasi oleh aparat penegak hukum. Selain menutupi kejahatan yang dilakukan, para pelaku kejahatan juga akan berupaya untuk menyamarkan atau menyembunyikan asal-usul harta kekayaan yang diperoleh dari kejahatan sedemikian rupa sehingga harta kekayaan tersebut seolah-olah berasal dari kegiatan yang sah berdasarkan ketentuan hukum yang berlaku. Kegiatan untuk menyamarkan atau menyembunyikan asal-usul harta kekayaan hasil kejahatan-dikenal dengan kegiatan pencucian uang merupakan bagian penting dari kejahatan terutama kejahatan dengan motif ekonomi seperti korupsi.
Tindak pidana pencucian uang dan tindak pidana asal
Di Indonesia, dengan berlakunya Undang-Undang Nomor 15 tahun 2002 sebagaimana telah diubah dengan Undang-Undang Nomor 25 Tahun 2003 tentang Tindak Pidana Pencucian Uang dan kemudian diganti dengan Undang-undang no 8 tahun 2010 tentang Pencegahan dan Pemberantasan Tindak Pidana Pencucian Uang, kegiatan pencucian uang merupakan suatu bentuk kejahatan tersendiri yang dapat dipisahkan dari kejahatan asalnya. Jadi, seseorang yang melakukan kejahatan, korupsi misalnya, kemudian menyembunyikan dan menyamarkan asal-usul harta kekayaan yang diperoleh dari kejahatan tersebut akan menghadapi 


\begin{tabular}{|c|c|}
\hline & $\begin{array}{l}\text { dua tuntutan yaitu tuntutan terhadap kejahatan atau } \\
\text { tindak pidana asal—dalam hal ini korupsi-dan tuntutan } \\
\text { terhadap kejahatan pencucian uang. } \\
\text { Undang-Undang Nomor } 15 \text { tahun } 2002 \text { sebagaimana } \\
\text { telah diubah dengan Undang-Undang Nomor } 25 \\
\text { Tahun } 2003 \text { tentang Tindak Pidana Pencucian Uang dan } \\
\text { kemudian diganti dengan Undang-undang Nomor } 8 \\
\text { tahun } 2010 \text { tentang Pencegahan dan Pemberantasan } \\
\text { Tindak Pidana Pencucian Uang mengartikan pencucian } \\
\text { uang sebagai segala perbuatan yang memenuhi unsur- } \\
\text { unsur tindak pidana sesuai dengan ketentuan dalam } \\
\text { Undang-Undang tersebut. }\end{array}$ \\
\hline $\begin{array}{l}\text { Tindak pidana asal } \\
\text { pencucian uang }\end{array}$ & $\begin{array}{l}\text { Pasal } 2 \text { ayat } 1 \text { Undang-Undang Nomor } 8 \text { tahun } 2010 \\
\text { tentang Pencegahan dan Pemberantasan Tindak Pidana } \\
\text { Pencucian Uang menyebutkan sedikitnya terdapat } 25 \\
\text { bentuk tindak pidana asal bagi pencucian uang dan } \\
\text { salah satu di antaranya adalah tindak pidana korupsi. }\end{array}$ \\
\hline $\begin{array}{l}\text { Hasil korupsi di } \\
\text { bidang kehutanan }\end{array}$ & $\begin{array}{l}\text { Seperti pada bentuk kejahatan dengan motif ekonomi } \\
\text { lainnya, korupsi di bidang kehutanan juga memberikan } \\
\text { hasil kejahatan dalam bentuk uang atau benda berharga } \\
\text { lainnya. Uang atau benda berharga yang diperoleh dari } \\
\text { suap, pemerasan atau gratifikasi yang langsung diterima } \\
\text { pejabat pemerintah di bidang kehutanan, misalnya, } \\
\text { merupakan hasil tindak pidana korupsi di bidang } \\
\text { kehutanan. Sementara itu, hasil penjualan hasil hutan } \\
\text { yang diperoleh tanpa izin yang seharusnya atau izinnya } \\
\text { diperoleh secara melawan hukum juga merupakan hasil } \\
\text { kejahatan korupsi bagi orang atau perusahaan yang } \\
\text { mengeksploitasi hasil hutan tersebut. }\end{array}$ \\
\hline $\begin{array}{l}\text { Pencucian uang hasil } \\
\text { korupsi di bidang } \\
\text { kehutanan }\end{array}$ & $\begin{array}{l}\text { Pelaku tindak pidana korupsi di bidang kehutanan } \\
\text { umumnya juga melakukan pencucian uang hasil } \\
\text { kejahatannya. Secara umum, terdapat tiga tahapan yang } \\
\text { harus dilakukan dalam pencucian uang, yaitu: } \\
\text { 1. Placement atau upaya menempatkan harta kekayaan } \\
\text { hasil kejahatan ke dalam suatu sistem keuangan; } \\
\text { 2. Layering atau memisahkan hasil kejahatan dari } \\
\text { sumbernya melalui beberapa tahap transaksi } \\
\text { keuangan untuk menyembunyikan atau } \\
\text { menyamarkan asal-usul harta kekayaan tersebut; }\end{array}$ \\
\hline
\end{tabular}


3. Integration atau upaya menggunakan harta kekayaan yang telah tampak sah, baik untuk dinikmati langsung, diinvestasikan ke dalam berbagai bentuk kekayaan material maupun keuangan, atau dipergunakan untuk membiayai kegiatan bisnis yang sah, ataupun untuk membiayai kembali kejahatan yang lain.

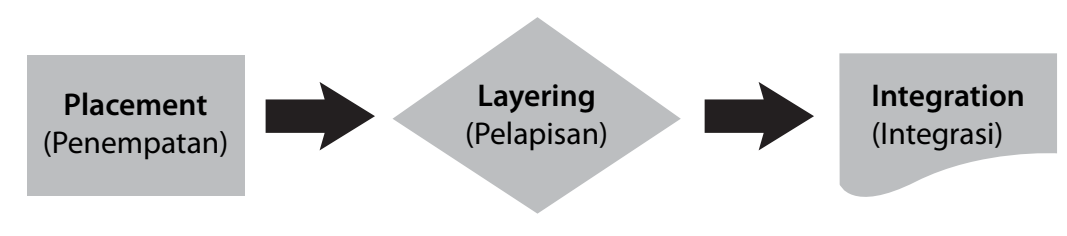

Dalam praktiknya, terdapat beberapa tipologi atau bentuk-bentuk umum teknik pencucian uang yang digunakan pelaku korupsi di bidang kehutanan untuk menyamarkan atau menyembunyikan hasil kejahatannya. Analisis yang dilakukan terhadap beberapa kasus korupsi di bidang kehutanan di Indonesia sebagai pidana asal menunjukkan penggunaan tipologi pencucian uang berikut ini:

- Mencampurkan atau memasukkan hasil kejahatan korupsi dalam bidang kehutanan ke dalam suatu kegiatan usaha yang sah;

- Memanfaatkan saudara, anggota keluarga atau orang kepercayaan untuk menerima dan mengelola harta hasil kejahatan, misalnya memanfaatkan ajudan untuk menerima hasil suap atas pemberian izin tertentu di bidang kehutanan;

- Menggunakan "perusahaan boneka" atau shell company atau perusahaan terafiliasi, termasuk perusahaan di luar negeri, untuk menerima, mengelola dan mendistribusikan harta hasil kejahatan.

Pencucian uang hasil kejahatan korupsi di bidang kehutanan merupakan rangkaian kejahatan yang dilakukan oleh pelaku kejahatan korupsi di bidang kehutanan. 



\section{Pelaksanaan Audit Investigatif terhadap Indikasi Korupsi dalam Bidang Kehutanan}

\subsection{Audit Investigatif Terhadap Indikasi Korupsi dalam Bidang Kehutanan}

Audit investigatif
Audit atau pemeriksaan investigatif adalah suatu bentuk audit atau pemeriksaan yang bertujuan untuk mengidentifikasi dan mengungkap kecurangan atau kejahatan dengan menggunakan pendekatan, prosedur dan teknik-teknik yang umumnya digunakan dalam suatu penyelidikan atau penyidikan terhadap suatu kejahatan.
Audit investigatif dan bentuk audit lainnya
Mengingat tujuan audit investigasi adalah untuk mengidentifikasi dan mengungkap kecurangan atau kejahatan, maka pendekatan, prosedur dan teknik yang digunakan di dalam audit investigatif relatif berbeda dengan pendekatan, prosedur dan teknik yang digunakan di dalam audit keuangan, audit kinerja atau audit dengan tujuan tertentu lainnya.

Dalam audit investigatif, seorang auditor memulai suatu audit dengan praduga akan adanya kemungkinan kecurangan dan kejahatan yang akan diidentifikasi dan diungkap melalui audit yang akan dilaksanakan. Kondisi tersebut, misalnya, akan mempengaruhi siapa yang akan diwawancarai terlebih dahulu atau dokumen apa yang harus dikumpulkan terlebih dahulu. Selain itu, dalam audit investigatif-jika memiliki kewenangan-auditor dapat menggunakan prosedur dan teknik 
yang umumnya digunakan dalam penyelidikan atau penyidikan kejahatan misalnya pengintaian, penggeledahan atau forensik komputer.

Audit investigatif terhadap indikasi korupsi merupakan audit investigatif yang diarahkan untuk mengidentifikasi dan mengungkap pelanggaran terhadap ketentuan di dalam undang-undang yang mengatur mengenai tindak pidana korupsi.

Undang-Undang pemberantasan tindak pidana korupsi
Di Indonesia, ketentuan mengenai tindak pidana korupsi diatur di dalam Undang-Undang Nomor 31 Tahun 1999 yang telah diperbarui dengan Undang-Undang Nomor 20 Tahun 2001 tentang Pemberantasan Tindak Pidana Korupsi.

Audit investigatif terhadap indikasi korupsi bisa dilaksanakan oleh auditor di lembaga negara dan lembaga pemerintah serta auditor di lembaga non-pemerintah.

Pelaksanaan audit investigatif di lembaga negara dan lembaga pemerintah terikat kepada ketentuan yang terdapat di dalam standar pemeriksaan keuangan negara atau SPKN. Sementara itu, pelaksanaan audit investigatif oleh auditor di lembaga non-pemerintah dapat mengacu kepada standar pemeriksaan yang dikeluarkan oleh lembaga yang memiliki otoritas untuk mengeluarkan standar seperti itu—di Indonesia misalnya Ikatan Akuntan Indonesia_-atau standar pemeriksaan yang lain tergantung kepada keterikatan antara auditor dengan pemberi mandat audit.

Audit investigatif, Audit investigatif terhadap indikasi korupsi mempunyai penyelidikan dan penyidikan hubungan yang erat dengan penyelidikan dan penyidikan korupsi yang dilaksanakan oleh aparat penegak hukum. Hal tersebut antara lain dapat digambarkan dengan penjelasan sebagai berikut.

- Hasil audit investigatif yang dilaksanakan oleh auditor dapat ditindaklanjuti dengan suatu penyelidikan atau penyidikan oleh penyelidik atau penyidik dari Kepolisian, Kejaksaan atau Komisi Pemberantasan Korupsi; 
- Penyelidik atau penyidik dari Kepolisian, Kejaksaan atau Komisi Pemberantasan Korupsi dapat meminta auditor untuk melaksanakan audit investigatif sebagai bagian dari penyelidikan atau penyidikan yang mereka lakukan;

- Jika indikasi korupsi teridentifikasi , pada umumnya auditor akan melakukan paparan atau expose di hadapan penyelidik atau penyidik dari Kepolisian, Kejaksaan atau Komisi Pemberantasan Korupsi sebelum menyusun laporan hasil audit investigatif;

- Laporan hasil audit investigatif yang dibuat oleh auditor atas dasar kekuatan sumpah jabatan/ profesi dapat digunakan sebagai alat bukti surat sebagaimana dimaksud dalam ps 184 ayat 3 jo dan ps 187 KUHAP.

Meskipun hasil audit investigatif telah dapat mengidentifikasi dan mengungkapkan kejahatan yang terjadi, penyelidik atau penyidik dari Kepolisian, Kejaksaan atau Komisi Pemberantasan Korupsi tetap harus melaksanakan penyelidikan dan penyidikan atas kejahatan yang terjadi. Hal tersebut terjadi karena, berdasarkan hukum acara pidana yang berlaku, penuntutan dan pemeriksaan di pengadilan hanya dapat dilaksanakan setelah dilaksanakannya penyelidikan dan penyidikan oleh aparat penegak hukum yang berwenang. Namun demikian, keberhasilan audit investigatif dalam mengidentifikasi dan mengungkapkan suatu kejahatan akan mengurangi volume pekerjaan dan waktu yang diperlukan untuk melakukan penyelidikan atau penyidikan oleh penyelidik atau penyidik dari Kepolisian, Kejaksaan atau Komisi Pemberantasan Korupsi.

\section{Pendekatan audit investigatif: Reaktif dan proaktif}

Sebagaimana halnya penyelidikan dan penyidikan, audit investigatif bisa dilaksanakan secara reaktif atau proaktif. Audit investigatif dikatakan bersifat reaktif apabila auditor melaksanakan audit setelah menerima atau mendapatkan informasi dari pihak lain mengenai kemungkinan adanya tindak kecurangan dan kejahatan. Sebaliknya, audit investigatif dikatakan bersifat proaktif apabila auditor secara aktif mengumpulkan informasi dan menganalisis informasi tersebut untuk menemukan kemungkinan adanya tindak kecurangan dan kejahatan sebelum melaksanakan audit investigatif. 
Audit investigatif yang bersifat reaktif umumnya dilaksanakan setelah auditor menerima atau mendapatkan informasi dari berbagai sumber informasi misalnya dari auditor lain yang melaksanakan audit reguler, dari pengaduan masyarakat, atau karena adanya permintaan dari aparat penegak hukum. Karena sifatnya yang reaktif maka auditor tidak akan melaksanakan audit jika tidak tersedia informasi tentang adanya dugaan atau indikasi kecurangan dan kejahatan.

Audit investigatif yang bersifat proaktif tidak menunggu. Auditor secara aktif mencari, mengumpulkan informasi dan menganalisis informasi-informasi yang diperoleh untuk menemukan kemungkinan adanya kecurangan dan kejahatan.

Audit investigatif yang bersifat proaktif perlu dilakukan pada area atau bidang-bidang yang memiliki potensi kecurangan atau kejahatan yang tinggi. Audit yang bersifat proaktif dapat menemukan kemungkinan adanya kecurangan dan kejahatan secara lebih dini sebelum kondisi tersebut berkembang menjadi kecurangan atau kejahatan yang lebih besar. Audit investigatif yang bersifat proaktif juga dapat menemukan kejahatan yang sedang atau masih berlangsung sehingga pengumpulan bukti untuk penyelidikan, penyidikan dan penuntutan kejahatan tersebut lebih mudah dilaksanakan.

Hasil dari suatu audit investigatif, baik yang bersifat reaktif maupun proaktif dapat digunakan sebagai dasar penyelidikan dan penyidikan kejahatan oleh aparat penegak hukum. Berdasarkan hasil audit tersebut, aparat penegak hukum akan mengumpulkan bukti-bukti yang relevan sesuai dengan kaidah hukum yang berlaku untuk kepentingan penuntutan dan pemeriksaan di pengadilan.

\section{Audit terbuka dan tertutup}

Audit investigatif dapat dilakukan secara terbuka ataupun secara tertutup. Audit secara terbuka dilakukan jika auditor secara eksplisit memberitahukan adanya pelaksanaan audit kepada auditee atau pihak yang diaudit. Sementara itu audit secara tertutup dilakukan jika auditor melaksanakan suatu audit investigatif namun tidak memberitahukan adanya kegiatan tersebut kepada pihak-pihak yang diaudit. 
Audit investigatif yang dilakukan oleh lembaga audit negara dan pemerintah pada umumnya adalah audit terbuka. Mereka mempunyai kewenangan yang bersumber dari ketentuan perundang-undangan yang berlaku. Dalam melaksanakan tugasnya, auditor negara dan auditor pemerintah menyampaikan secara resmi surat tugas audit kepada pihak yang diaudit. Meskipun dikatakan terbuka, dalam mengumpulkan bukti, auditor tetap dapat menggunakan teknik-teknik audit tertutup. Selain itu, auditor harus tetap membatasi akses informasi yang diperoleh hanya kepada pihak-pihak yang memang mempunyai kepentingan terhadap audit yang dilaksanakan.

Audit investigatif tertutup dapat dilaksanakan oleh mereka yang secara resmi tidak memiliki kewenangan untuk mengaudit suatu kegiatan. Karena adanya keterbatasan kewenangan dalam melaksanakan audit investigatif secara tertutup maka auditor harus mencari sumber-sumber informasi alternatif dengan menggunakan prosedur audit alternatif selain sumber informasi dan prosedur konvensional dalam mencari bukti-bukti yang diperlukan dalam audit.

Kualifikasi auditor
Audit investigatif seharusnya dilaksanakan oleh mereka yang mempunyai pengalaman dan keahlian dalam melaksanakan audit investigatif. Auditor yang belum memiliki pengalaman dan keahlian harus mendapat bimbingan dari auditor lain yang memiliki pengalaman dan keahlian audit investigatif. Auditor investigatif juga perlu mempunyai pemahaman yang cukup tentang hal-hal yang akan diaudit terutama menyangkut peraturan yang berlaku serta proses bisnis yang berkaitan dengan hal-hal yang akan diaudit. Secara khusus, auditor yang akan melaksanakan audit investigatif juga harus mempunyai pemahaman yang cukup tentang ketentuan-ketentuan hukum yang berkaitan dengan hal-hal yang akan diaudit maupun ketentuan-ketentuan hukum yang berkaitan dengan pengungkapan kejahatan misalnya Kitab Undang-Undang Hukum Acara Pidana atau KUHAP. 


\section{Mekanisme audit Audit investigatif untuk menemukan kemungkinan adanya korupsi di bidang kehutanan dilaksanakan dengan mengikuti langkah-langkah sebagai berikut. \\ 1. Mengumpulkan data dan informasi serta menganalisis adanya indikasi korupsi; \\ 2. Mengembangkan hipotesis kejahatan dan merencanakan audit; \\ 3. Melaksanakan audit untuk mengumpulkan bukti- bukti yang mendukung hipotesis; \\ 4. Menyusun laporan hasil audit.}

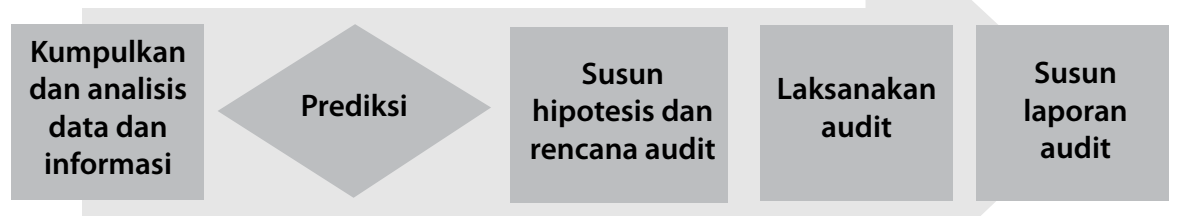

\subsubsection{Pengumpulan Data dan Informasi serta Analisis adanya Indikasi Korupsi}

Pengumpulan data dan informasi
Audit investigatif yang bersifat proaktif dimulai dengan pengumpulan data dan informasi yang berkaitan dengan permasalahan yang akan diaudit. Terdapat sejumlah besar data dan informasi yang dapat dikumpulkan dari berbagai sumber untuk mengidentifikasi adanya indikasi kecurangan dan kejahatan. Selanjutnya berbagai data dan informasi tersebut dianalisis sesuai dengan tujuan dari audit investigatif yang akan dilaksanakan.

Jika audit investigatif diarahkan untuk menemukan adanya indikasi korupsi di bidang kehutanan maka informasi-informasi di bawah ini dapat dikumpulkan dan dianalisis oleh auditor untuk menemukan adanya penyimpangan atau pelanggaran yang merugikan keuangan negara, pemerasan, penyuapan atau bentukbentuk korupsi yang lainnya.

1. Citra satelit atau foto udara;

2. Data geo-spasial; 
3. Data pemberian hak dan izin yang berkaitan dengan hutan;

4. Data produksi hasil hutan;

5. Data penerimaan dana reboisasi dan provisi sumber daya hutan serta data penerimaan negara dan penerimaan daerah lainnya;

6. Data kekayaan penyelenggara negara;

7. Informasi dari media massa;

8. Informasi dari lembaga swadaya masyarakat atau informasi langsung dari masyarakat;

9. Laporan hasil pemeriksaan Badan Pemeriksa Keuangan dan aparat pengawasan internal pemerintah;

10. Data perusahaan dan pengusaha dalam bidang kehutanan atau bidang lain berkaitan dengan bidang kehutanan;

11. Direktori bisnis dalam bidang kehutanan atau bidang lain yang berkaitan dengan bidang kehutanan.

\section{Citra Satelit dan Foto Udara}

Citra satelit adalah hasil penginderaan jarak jauh melalui satelit yang menggambarkan penampakan dari suatu area di permukaan bumi. Sementara itu, foto udara adalah hasil pemotretan dari udara dengan menggunakan perangkat pemotretan yang ditempatkan di pesawat, helikopter atau benda terbang lainnya yang juga menggambarkan penampakan dari suatu area di permukaan bumi. Karena diambil dari jarak yang jauh, citra satelit pada umumnya mencakup penampakan suatu kawasan yang lebih luas dibandingkan dengan foto udara. Sebaliknya, foto udara, yang diambil dari jarak yang lebih dekat, pada umumnya akan memberikan gambaran yang lebih rinci.

Satu citra satelit atau foto udara bisa menggambarkan kondisi suatu area kawasan hutan pada saat tertentu. Sementara dua atau lebih citra satelit atau foto udara pada area yang sama dapat menggambarkan kondisi suatu area kawasan hutan selama periode tertentu sehingga bisa menggambarkan perkembangan deforestasi di suatu area di kawasan hutan. 
Untuk kepentingan analisis, informasi yang diperoleh dari citra satelit atau foto udara dapat dikombinasikan dengan data geo-spasial untuk area yang bersangkutan, misalnya data geo-spasial mengenai peruntukan atau pemanfaatan kawasan hutan. Dengan data tersebut, analisis yang dilaksanakan dapat menunjukkan adanya indikasi kecurangan atau kejahatan sebagai berikut:

- Adanya pemanenan atau pemungutan hasil hutan kayu di kawasan hutan yang seharusnya tidak boleh dieksploitasi;

- Adanya pemanenan atau pemungutan hasil hutan kayu yang tidak sesuai atau melebihi rencana pemanenan atau pemungutan yang sudah ditetapkan;

- Adanya praktik tebang habis di suatu kawasan hutan.

Analisis terhadap citra satelit dan foto udara juga dapat diperkuat dengan pelaksanaan observasi secara langsung ke lapangan. Observasi lapangan dapat memberikan gambaran yang realistik mengenai kondisi terkini dari suatu kawasan hutan.

Citra satelit dan foto udara umumnya digunakan untuk membuktikan adanya deforestasi di suatu kawasan hutan baik dalam pelaksanaan audit investigatif maupun dalam penyelidikan, penyidikan, penuntutan atau pemeriksaan di pengadilan. Khusus untuk kepentingan penuntutan dan pemeriksaan di pengadilan, bukti dalam bentuk citra satelit atau foto udara umumnya akan dihubungkan dengan bukti yang lain dalam bentuk keterangan saksi atau keterangan ahli.

Citra satelit atau foto udara dapat diperoleh dengan mengunduh secara cuma-cuma dari internet, khususnya untuk citra atau foto yang sudah berusia lama, atau membeli dari pemilik satelit atau foto udara atau lembaga lain yang menyediakan benda-benda tersebut.

\section{Data Geo-Spasial}

Data geo-spasial adalah data yang dihasilkan dari suatu sistem informasi geografik yang menggambarkan kondisi permukaan bumi, peruntukan ataupun pemanfaatan suatu kawasan di permukaan bumi. Data geo-spasial misalnya dapat menggambarkan tata ruang di suatu kawasan atau batas-batas peruntukan kegiatan usaha di bidang kehutanan. 
Analisis data geo-spasial seringkali dikombinasikan dengan analisis terhadap citra satelit atau foto udara dan observasi langsung ke suatu kawasan. Analisis terhadap data geo-spasial dapat menunjukkan kemungkinan adanya kecurangan dan kejahatan seperti:

- $\quad$ Adanya pemberian hak atau izin di bidang kehutanan yang tidak sesuai dengan peruntukannya menurut ketentuan mengenai tata ruang;

- Adanya tumpang tindih dalam pemberian hak atau izin di bidang kehutanan di suatu kawasan.

Data geo-spasial dapat diperoleh dari lembaga-lembaga yang mempunyai kewenangan dalam peruntukan dan pemanfaatan tata ruang atau lembaga-lembaga yang melakukan kegiatan pemetaan. Data geo-spasial juga dapat dihasilkan dengan menambahkan data-data tertentu ke suatu peta dasar dengan menggunakan perangkat lunak tertentu.

\section{Data Pemberian Hak dan Izin yang Berkaitan dengan Hutan}

Data yang berkaitan dengan pemberian hak dan izin yang berkaitan dengan hutan pada umumnya dikuasai oleh lembaga-lembaga yang memberikan hak atau izin. Auditor pemerintah dapat mengakses data tersebut sesuai dengan kewenangan yang dimilikinya.

Analisis terhadap data seperti ini umumnya ditujukan untuk menguji ketaatan pelaksanaan pemberian hak dan izin dibandingkan dengan ketentuan yang berlaku. Dalam analisis seperti ini, auditor akan melaksanakan sejumlah kegiatan yaitu:

- Mengumpulkan peraturan yang mendasari pemberian suatu hak dan izin;

- Menyimpulkan proses serta persyaratan yang harus dipenuhi pada setiap tahapan pemberian hak atau izin yang bersangkutan;

- Membandingkan antara proses dan persyaratan yang seharusnya dipenuhi dengan proses dan persyaratan yang benar-benar dilaksanakan.

Jika Auditor menemukan adanya perbedaan antara yang seharusnya dilaksanakan dengan yang sesungguhnya dilaksanakan maka Auditor telah menemukan unsur melawan hukum yang merupakan indikasi adanya tindak kecurangan atau kejahatan. 


\section{Data Produksi Hasil Hutan}

Datar produksi hasil hutan adalah data-data yang berkaitan dengan kegiatan-kegiatan usaha di bidang kehutanan, misalnya data pemungutan dan pemanenan hasil hutan dalam bentuk kayu atau non kayu, data produksi kayu olahan, data pengiriman atau ekspor hasil hutan, data penerimaan dana reboisasi dan provisi sumber daya hutan, dan lain sebagainya.

Analisis terhadap data produksi hasil hutan antara lain dapat dilakukan dalam bentuk:

- Pembandingan data produksi hasil hutan dengan jumlah pembayaran dana reboisasi dan provisi sumber daya hutan, baik secara keseluruhan maupun untuk setiap entitas usaha di bidang kehutanan yang dapat menunjukkan adanya penyimpangan pelaporan produksi atau pembayaran penerimaan dana reboisasi dan provisi sumber daya hutan;

- Pembandingan antara data pengiriman kayu dari pelabuhan asal dengan penerimaan kayu di pelabuhan tujuan yang dapat menunjukkan adanya kayu yang dikirimkan ke pelabuhan lain di luar pelabuhan tujuan, termasuk kemungkinan penyelundupan kayu ke pelabuhan di luar negeri;

- Pembandingan antara data ekspor kayu dari Indonesia ke suatu negara lain dengan data impor kayu negara yang bersangkutan dari Indonesia yang dapat menunjukkan adanya kemungkinan penyelundupan kayu dari Indonesia ke negara tersebut.

Analisis lebih lanjut terhadap indikasi kecurangan atau kejahatan di atas dapat mengarah kepada adanya indikasi korupsi dalam produksi hasil hutan.

\section{Data Penerimaan Dana Reboisasi dan Provisi} Sumber Daya Hutan serta Penerimaan Negara dan Penerimaan Daerah Lainnya

Data penerimaan dana reboisasi dan provisi sumber daya hutan merupakan data penerimaan pemerintah atas pemungutan dan pemanenan hasil hutan sesuai dengan ketentuan yang mengatur tentang dana reboisasi dan provisi sumber daya hutan. 
Data produksi hasil hutan dapat dibandingkan dengan realisasi penerimaan dana reboisasi dan provisi sumber daya hutan, baik secara keseluruhan maupun untuk setiap entitas usaha di bidang kehutanan. Pembandingan tersebut dapat menunjukkan adanya penyimpangan pelaporan produksi atau pembayaran penerimaan dana reboisasi dan provisi sumber daya hutan. Hal yang serupa dapat dilakukan terhadap penerimaan negara atau penerimaan daerah yang berkaitan dengan kegiatan di bidang kehutanan.

\section{Data Kekayaan Penyelenggara Negara}

Data kekayaan penyelenggara negara yang dipublikasikan dapat diperoleh dari Kompilasi Laporan Harta Kekayaan Penyelenggara Negara (LHKPN) yang dimiliki oleh Komisi Pemberantasan Korupsi (KPK) maupun Perum Percetakan Negara.

Salah satu analisis yang bisa dilakukan terhadap data kekayaan seorang penyelenggara negara adalah dengan melakukan prosedur analitikal menggunakan pendekatan net worth theory atau teori kekayaan bersih dengan cara sebagai berikut:

1. hitung kenaikan harta kekayaan dengan cara mengurangi kekayaan bersih di akhir periode dengan kekayaan bersih di awal periode;

2. hitung penghasilan bersih selama periode pemeriksaan dengan cara mengurangi seluruh penghasilan dengan seluruh pengeluaran pada periode pemeriksaan;

3. jika terdapat penerimaan atau pengeluaran hibah, warisan, atau hadiah maka hal tersebut harus menambah atau mengurangi penghasilan bersih;

4. bandingkan kenaikan harta kekayaan dengan penghasilan bersih selama periode pemeriksaan;

5. jika kenaikan harta kekayaan lebih rendah daripada penghasilan bersih yang diperoleh selama periode pemeriksaan maka selisihnya adalah pengeluaran yang tidak diketahui penggunaannya; 
6. jika kenaikan harta kekayaan lebih tinggi daripada penghasilan bersih yang diperoleh selama periode pemeriksaan maka selisihnya adalah kenaikan harta kekayaan yang berasal dari sumber penghasilan yang tidak diketahui termasuk yang kemungkinan bersumber dari kecurangan atau kejahatan.

\section{Informasi dari Media Massa}

Informasi dari koran, televisi, radio, internet merupakan informasi yang berharga yang dapat digunakan sebagai bahan untuk menganalisis kemungkinan adanya kecurangan atau kejahatan.

Informasi dari koran, televisi, radio, internet dapat digunakan untuk mengetahui secara mendalam latar belakang suatu peristiwa, riwayat hidup seseorang yang diduga melakukan kecurangan atau kejahatan atau kegiatan usaha suatu perusahaan yang diduga melanggar suatu ketentuan yang berlaku.

Informasi dari koran atau media massa cetak berkala lainnya dapat diperoleh dari perpustakaan atau pusat data koran atau media yang bersangkutan. Informasi dari koran atau media massa cetak berkala lainnya tidak hanya menyajikan informasi yang mutakhir tetapi juga informasi yang berasal dari periode beberapa tahun yang lalu.

\section{Informasi dari Lembaga Swadaya Masyarakat atau Informasi Langsung dari Masyarakat}

Banyak informasi yang berasal dari lembaga swadaya masyarakat atau dari masyarakat secara langsung yang dapat dimanfaatkan untuk mendukung suatu analisis. Seringkali, lembaga swadaya masyarakat atau masyarakat secara langsung menyaksikan adanya kecurangan atau kejahatan sehingga mengetahui sebagian besar atau bagian tertentu dari suatu kecurangan atau kejahatan.

\section{Laporan Hasil Pemeriksaan Badan Pemeriksa Keuangan dan Aparat Pengawasan Internal Pemerintah}

Secara berkala, auditor Badan Pemeriksa Keuangan atau auditor internal pemerintah melakukan audit terhadap lembaga-lembaga pemerintah atau lembaga lainnya. Hasil dari pemeriksaan ini diungkapkan di dalam suatu laporan hasil pemeriksaan. 
Laporan dari hasil audit keuangan atau audit kinerja yang secara reguler yang dilaksanakan oleh auditor pemerintah terkadang menyebutkan adanya kesalahan yang bersifat administratif yang jika dianalisis secara mendalam sesungguhnya mengindikasikan adanya kemungkinan kecurangan atau kejahatan yang lebih serius yang belum dapat terungkap dengan pendekatan audit reguler tersebut. Seseorang yang memiliki keahlian mendalam dalam bidang kehutanan akan dapat menganalisis hasil pemeriksaan reguler di bidang kehutanan dari sisi pandang yang relatif berbeda dengan auditor dan menemukan adanya indikasi kecurangan atau kejahatan yang tidak diungkapkan dalam laporan hasil pemeriksaan.

Pada lembaga tertentu, seperti Badan Pemeriksa Keuangan, hasil pemeriksaan ini dipublikasikan secara luas melalui internet sehingga bisa diakses oleh masyarakat luas.

\section{Data Perusahaan dan Pengusaha dalam Bidang Kehutanan atau Bidang Lain yang Berkaitan dengan Bidang Kehutanan}

Data perusahaan dan pengusaha diperlukan dalam hal seorang auditor memerlukan informasi lebih mendalam mengenai perusahaan atau pengusaha yang diduga melakukan kecurangan atau kejahatan dalam bidang kehutanan.

Data perusahaan dan data pengusaha dalam bidang kehutanan atau bidang lain yang berkaitan dengan bidang kehutanan dapat diperoleh dari lembaga pemerintah yang mengeluarkan hak dan izin, asosiasi bisnis, atau lembaga yang menerbitkan direktori atau buku kumpulan informasi mengenai kegiatan usaha tertentu.

\section{Direktori Bisnis dalam Bidang Kehutanan atau Bidang Lain yang Berkaitan dengan Bidang Kehutanan}

Direktori bisnis memuat data pelaku usaha dalam bidang tertentu termasuk bidang kehutanan atau bidang lain yang berkaitan dengan bidang kehutanan dan dapat diperoleh dari lembaga yang menghimpun data bisnis survei kegiatan usaha. 
Direktori bisnis bisa diperoleh dengan mencari dan membeli direktori tersebut dari penerbit yang bersangkutan atau mencari direktori yang sama di perpustakaan.

Analisis data dan informasi
Salah satu pendekatan yang dapat digunakan oleh auditor dalam menganalisis data dan informasi untuk mengidentifikasi adanya indikasi kecurangan atau kejahatan di bidang kehutanan adalah sebagai berikut:

1. Lakukan analisis terhadap perkembangan deforestasi di suatu area dengan membandingkan citra satelit atau foto udara pada suatu periode tertentu. Berdasarkan analisis, tentukan lokasi dan luasan pertambahan deforestasi dari waktu ke waktu dalam periode yang dianalisis untuk menentukan dimana dan kapan kecurangan atau kejahatan terjadi serta berapa besar kerugian yang terjadi.

2. Jika terjadi deforestasi pada suatu area yang luas, dapatkan informasi yang berkaitan dengan area tersebut misalnya ketentuan mengenai tata ruang serta pemberian hak dan izin pada area yang bersangkutan.

3. Jika terhadap area yang terdeforestasi telah diberikan hak atau izin yang berkaitan dengan bidang kehutanan tertentu maka dapatkan:

- $\quad$ informasi mengenai ketentuan yang mengatur mengenai pemberian hak dan izin serta penyelenggara negara atau pejabat negara yang terlibat di dalam pemberian hak atau izin;

- dokumen-dokumen yang diajukan oleh pemohon hak atau izin dalam rangka memperoleh hak atau izin tersebut;

- dokumen-dokumen yang telah dikeluarkan oleh lembaga negara atau lembaga pemerintah yang terlibat dalam pemberian hak atau izin tersebut.

4. Lakukan observasi lapangan untuk mengetahui secara mendalam gambaran deforestasi dan kondisi hutan yang sesungguhnya pada saat sekarang.

5. Dapatkan data dan informasi tambahan mengenai pejabat negara yang terlibat di dalam pemberian hak atau izin, terutama mengenai laporan harta kekayaan yang bersangkutan. 
6. Lakukan analisis untuk memperkirakan siapa yang paling mungkin melakukan atau terlibat dalam kegiatan yang mengakibatkan deforestasi serta mengapa dan bagaimana mereka melakukan hal tersebut.

\section{Kesimpulan} hasil analisis dan tindak lanjut hasil analisis
Dari analisis yang dilakukan, auditor harus menyusun suatu kesimpulan mengenai indikasi kecurangan atau kejahatan yang telah terjadi. Kesimpulan dapat disusun sedemikian rupa sehingga secara keseluruhan bisa menjawab pertanyaan-pertanyaan berikut:

1. Siapa (Who) orang, kelompok orang atau korporasi yang melakukan kecurangan atau kejahatan?

2. Siapa (Who) saja pihak yang dapat membantu memberikan keterangan tentang orang-orang yang dicurigai terlibat tersebut?

3. Kecurangan atau kejahatan Apa (What) yang dilakukan?

4. Kapan (When) pelaku melakukan kecurangan atau kejahatan?

5. Di mana (Where) pelaku melakukan kecurangan atau kejahatan?

6. Mengapa (Why) pelaku melakukan kecurangan atau kejahatan?

7. Bagaimana (How) pelaku melakukan kecurangan atau kejahatan?

Khusus untuk kejahatan dalam bentuk tindak pidana korupsi tertentu ada satu pertanyaan lagi yang juga perlu dicari jawabannya yaitu Seberapa (How much) besar kerugian negara yang timbul sebagai akibat dari kejahatan yang telah dilakukan pelaku kejahatan.

\section{Predikasi}

Dalam tahapan analisis maka tidak semua pertanyaan di atas dapat dijawab. Akan tetapi suatu audit investigatif dapat dimulai jika terdapat suatu predikasi atau dasar yang kuat untuk melaksanakan suatu audit investigasi. Adanya predikasi ditunjukkan dengan adanya jawaban sementara atas tiga pertanyaan dari enam pertanyaan di atas, yaitu:

1. Kecurangan atau kejahatan Apa (What) yang dilakukan? 
2. Kapan (When) pelaku melakukan kecurangan atau kejahatan?

3. Di mana (Where) pelaku melakukan kecurangan atau kejahatan?

Suatu contoh hasil analisis yang berkaitan dengan kecurangan atau kejahatan di bidang kehutanan yang sudah mempunyai suatu predikasi misalnya adalah:

- $\quad$ Antara bulan Oktober dan Desember 2007, Direksi perusahaan X melakukan penebangan di luar kawasan yang diizinkan di area Taman Nasional Kerinci Seblat;

- Suatu kelompok masyarakat yang dipimpin Y melakukan penebangan di area hutan konservasi di Kabupaten Ketapang pada bulan Juli 2008;

- Direksi perusahaan Z tidak membayar Dana Reboisasi dan Provisi Sumber Daya Hutan tahun 2007 sesuai dengan realisasi produksi perusahaan yang bersangkutan.

Jika sudah terdapat suatu predikasi maka auditor dapat mengembangkan hipotesis kecurangan atau kejahatan yang terjadi dan menyusun perencanaan audit.

\section{1 .2}

\section{Pengembangan Hipotesis Kecurangan atau Kejahatan dan Perencanaan Audit}

Setelah menemukan adanya predikasi, seorang auditor harus mengembangkan hipotesis atau dugaan sementara mengenai kecurangan atau kejahatan yang terjadi. Hipotesis dikembangkan dari informasi yang sudah dikumpulkan dan analisis yang sudah dilakukan atas informasi tersebut.

Suatu contoh dari hipotesis yang dikembangkan dari analisis terhadap informasi yang telah dikumpulkan seorang auditor adalah sebagai berikut:

- Direksi perusahaan Z memalsukan dokumen laporan hasil produksi sehingga Dana Reboisasi dan Provisi Sumber Daya Hutan tahun 2007 yang dibayarkan lebih kecil dari jumlah yang seharusnya dibayarkan pada tahun yang bersangkutan. 
Penyusunan hipotesis bertujuan agar audit bisa dilaksanakan mengarah kepada pembuktian hipotesis. Namun demikian, seiring dengan perkembangan bukti yang dikumpulkan selama pelaksanaan audit, hipotesis bisa saja berubah.

Berdasarkan hipotesis yang disusun sebelum melakukan pemeriksaan, auditor menyusun perencanaan audit yang antara lain mencakup:

1. Penyusunan Program Kerja Audit;

2. Penyusunan Tim Audit;

3. Penyusunan Rencana Biaya Audit.

\section{Penyusunan program kerja audit}

Program Kerja Audit adalah serangkaian teknik dan prosedur audit yang disusun secara sistematis yang akan dilaksanakan untuk mengumpulkan bukti-bukti dalam rangka menguji hipotesis yang telah ditetapkan. Dalam menyusun program kerja audit maka auditor harus memperhatikan tujuan dari audit dan kewenangan yang dimiliki oleh para auditor. Jika auditor mendapat kesulitan untuk melaksanakan teknik atau prosedur audit tertentu maka dia harus mencari teknik atau prosedur alternatif yang dapat digunakan untuk mencapai tujuan yang sama.
Berdasarkan program kerja pemeriksaan maka auditor dapat memperkirakan susunan tim audit. Pada umumnya, dalam suatu audit investigatif sebuah tim akan terdiri dari:

1. Seorang penyelia audit atau audit supervisor;

2. Seorang ketua tim audit atau audit team leader;

3. Seorang atau beberapa orang anggota tim audit, tergantung kepada seberapa luas ruang lingkup pemeriksaan audit investigatif.

Untuk audit dengan skala pekerjaan yang besar dan membutuhkan banyak auditor maka dapat dibentuk subsub tim yang menangani penugasan tertentu dari audit secara keseluruhan.

Pada kasus tertentu, tim audit dapat dibantu dengan para ahli yang mempunyai pengetahuan atau kemampuan profesional di bidang tertentu, misalnya untuk penghitungan besarnya kerugian negara karena kerusakan hutan. 


\section{Penyusunan rencana biaya audit \\ Berdasarkan program kerja pemeriksaan maka auditor juga dapat memperkirakan biaya yang diperlukan untuk mendukung pelaksanaan audit. Biaya audit harus mencakup seluruh biaya yang diperlukan untuk mengumpulkan bukti dalam pelaksanaan audit serta melaporkan dan menyampaikan hasil audit kepada pihak-pihak yang ditentukan. \\ Jika auditor telah menyusun dan menetapkan perencanaan audit maka audit investigatif dapat mulai dilaksanakan.}

\subsection{3}

\section{Pelaksanaan Audit}

\section{Teknik audit}

Dalam rangka membuktikan hipotesis yang telah ditetapkan, auditor dapat melaksanakan teknik-teknik audit berikut ini:

1. Meminta dan menganalisis dokumen, baik dokumen yang berbentuk fisik maupun non-fisik;

2. Wawancara, baik wawancara biasa maupun wawancara mendalam;

3. Melaksanakan pemeriksaan fisik dan observasi lapangan;

4. Mengakses data dan informasi dari perangkat, sistem atau basis data tertentu;

5. Melakukan konfirmasi;

6. Melaksanakan tinjauan analitikal;

7. Melaksanakan pengintaian;

8. Melakukan pengambilan gambar atau suara.

Setiap bentuk teknik audit memiliki keunggulan sekaligus kelemahan tersendiri sehingga seorang auditor harus secara tepat memilih teknik audit yang akan digunakan sesuai dengan kebutuhan pelaksanaan audit dan kewenangan yang dimiliki auditor.

\subsubsection{1}

Meminta dan Menganalisis Dokumen

Dokumen-dokumen tertulis yang secara langsung maupun tidak langsung menunjukkan adanya kecurangan atau kejahatan merupakan bukti-bukti yang sangat penting dalam audit, penyelidikan, penyidikan, penuntutan maupun pemeriksaan di pengadilan. 
Namun demikian, kemampuan auditor untuk memperoleh dokumen-dokumen tertulis yang dibutuhkan sangat dipengaruhi oleh kewenangan yang dimiliki oleh seorang auditor. Jika seorang auditor tidak memiliki kewenangan untuk meminta secara langsung dokumen-dokumen tertulis yang dibutuhkannya, maka auditor tersebut harus mencari sumber-sumber data dan informasi lain atau menggunakan teknik audit alternatif untuk memperoleh data dan informasi yang dibutuhkan dengan tetap memperhatikan ketentuan-ketentuan hukum yang berlaku.

\section{Bukti langsung dan tidak langsung}

Dokumen-dokumen tertulis dapat menjadi bukti langsung (direct evidence) atau tidak langsung (circumstantial evidence) dari suatu kecurangan atau kejahatan. Dokumen tertulis akan menjadi bukti langsung jika dokumen tersebut memuat informasi yang secara langsung menunjukkan adanya suatu kecurangan atau kejahatan. Termasuk dalam pengertian bukti langsung adalah keputusan pejabat pemerintah yang menyimpang dari ketentuan yang berlaku atau cek yang diterima pejabat pemerintah berkaitan dengan suatu penyuapan. Sementara itu, bukti tidak langsung adalah dokumen-dokumen yang jika dihubungkan dengan dokumen yang lain akan membentuk suatu rangkaian yang menunjukkan adanya kecurangan atau kejahatan. Sesuai dengan ketentuan hukum di Indonesia, bukti langsung dapat menjadi bukti surat sementara bukti tidak langsung dapat menjadi bukti petunjuk.

Seorang auditor tidak memiliki kewenangan untuk menyita suatu dokumen. Dengan demikian terdapat risiko hilangnya dokumen-dokumen penting yang didapatkan di dalam audit dan dapat dijadikan bukti adanya kecurangan atau kejahatan dalam penyelidikan dan penyidikan. Dalam kondisi seperti ini maka auditor dapat meminta salinan dokumen tersebut dengan pernyataan bahwa salinan tersebut sama dengan dokumen yang bersangkutan. Selain itu auditor dapat meminta pernyataan dari orang yang bertanggung jawab terhadap keberadaan dokumen tersebut dan juga atasannya bahwa mereka mengakui keberadaan dokumen tersebut, bertanggung jawab penuh terhadap dokumen tersebut serta akan menyimpan dan menjaga dokumen tersebut dengan sebaik-baiknya. 


\subsubsection{2}

\section{Wawancara}

Wawancara merupakan suatu teknik audit dalam bentuk percakapan tanya jawab dalam rangka menggali suatu informasi. Dalam audit, wawancara bukan merupakan percakapan biasa karena umumnya dilaksanakan secara terstruktur dengan maksud dan tujuan mengungkap suatu kecurangan atau kejahatan.

Sebelum melakukan wawancara, seorang auditor harus menentukan strategi terlebih dahulu. Strategi tersebut antara lain akan menentukan siapa yang terlebih dahulu diwawancarai, siapa yang akan melakukan wawancara, serta kapan dan dimana wawancara akan dilakukan. Dalam menentukan strategi wawancara, seorang auditor perlu memperhatikan hal-hal sebagai berikut:

- Urutan wawancara sebaiknya dimulai dari orang yang paling mudah memberikan informasi yang diperlukan, misalnya orang-orang yang paling lemah atau orang-orang memiliki kepentingan yang berseberangan dengan orang-orang yang melakukan kecurangan atau kejahatan;

- Wawancara yang dilaksanakan di tempat kerja orang yang diwawancarai akan memberikan kenyamanan dan rasa percaya diri yang lebih tinggi dibandingkan dengan wawancara di tempat yang asing bagi orang yang diwawancarai.

Dalam suatu wawancara, terdapat lima jenis pertanyaan yang umumnya ditanyakan kepada orang yang diwawancarai yaitu:

1. Pertanyaan pembuka yang mengawali wawancara sekaligus untuk membuat orang yang diwawancarai mau bekerjasama;

2. Pertanyaan untuk mendapatkan atau menggali informasi;

3. Pertanyaan untuk menilai, terutama dalam hal orang yang diwawancarai cenderung berbohong, dapat dilakukan dengan mengajukan pertanyaan hipotetik dan tidak bersifat menuduh. Orang yang melakukan wawancara dapat menilai dari jawaban yang diberikan dan juga tanggapan non verbal dari gaya dan bahasa tubuh orang yang diwawancarai; 
4. Pertanyaan untuk mendapatkan pengakuan dari orang yang diduga melakukan kecurangan atau kejahatan;

5. Pertanyaan penutup pada bagian akhir suatu wawancara untuk mengkonfirmasi suatu informasi tertentu.

Selain memperhatikan jawaban yang diberikan, seorang auditor yang melakukan wawancara juga harus memperhatikan tanggapan non verbal untuk menilai kebenaran dari suatu jawaban. Gaya dan bahasa tubuh yang seringkali menunjukkan adanya kebohongan antara lain adalah:

- Perubahan pola percakapan yang bisa berupa pelambatan atau percepatan tempo bicara atau keras-kecilnya volume suara, batuk, berdehem dan sebagainya;

- Pengulangan pertanyaan dalam rangka mendapatkan waktu tambahan untuk memikirkan jawaban yang ingin diberikan;

- Komentar menyangkut wawancara, misalnya mengeluhkan mengenai kondisi ruangan yang digunakan untuk wawancara;

- Ingatan selektif yaitu lebih ingat secara mendalam kepada bagian-bagian yang tidak begitu penting tetapi cenderung melupakan bagian-bagian yang lebih penting;

- Bersumpah yaitu dengan menyatakan suatu sumpah misalnya dengan menggunakan kata-kata "Demi Tuhan ..."

- Mengokohkan karakter dirinya misalnya dengan menyatakan "tanyakan soal kejujuran saya kepada orang tua saya ..."

- Memberikan jawaban dalam bentuk pertanyaan;

- Sikap yang toleran terhadap suatu kesalahan, misalnya "sebaiknya mereka tidak langsung dihukum ..."

- Keengganan mengakhiri wawancara;

- Gerakan tubuh menjauh dalam hal mendapat pertanyaan yang sensitif;

- Menyilangkan tangan di dada sebagai reaksi dari pertanyaan yang sulit dijawab;

- Tubuh yang banyak berkeringat, detak jantung meningkat, tarikan nafas panjang merupakan reaksi tubuh yang bisa terlihat. 


\subsubsection{3}

\section{Melaksanakan Pemeriksaan Fisik dan Observasi Lapangan}

Pemeriksaan fisik dan observasi lapangan adalah pemeriksaan langsung yang dilakukan oleh seorang auditor untuk mengetahui kondisi sesungguhnya dari suatu obyek yang diperiksa.

Dalam audit investigatif yang berkaitan dengan bidang kehutanan, pemeriksaan fisik dan observasi lapangan bisa dilakukan terhadap suatu area yang terdeforestasi. Pemeriksaan atau observasi seperti itu dapat memberikan keyakinan kepada auditor bahwa kerusakan hutan memang sudah terjadi dan luas kerusakan hutan dapat dihitung secara lebih pasti. Dengan tambahan foto dan rekaman video serta berita acara pemeriksaan atau observasi, auditor dapat meyakinkan pihak lain mengenai hasil pemeriksaan atau observasi yang dilakukannya.

2.1.3.4

Mengakses Data dan Informasi dari Perangkat, Sistem atau Basis Data Tertentu;

Auditor dapat mengakses data dan informasi dari perangkat, sistem atau basis data tertentu dengan menggunakan mekanisme forensik komputer. Selain dokumen-dokumen tertulis, bukti-bukti elektronik atau bukti digital dalam bentuk surat elektronik (electronic mail), layanan pesan singkat (short message service/sms) atau dokumen yang tersimpan di dalam perangkat, sistem atau basis data tertentu merupakan bukti-bukti yang dapat digunakan dalam audit, penyelidikan, penyidikan, penuntutan dan pemeriksaan di pengadilan. Mengingat karakteristik bukti elektronik atau bukti digital yang mudah rusak maka pengambilan bukti tersebut harus dilakukan oleh seseorang yang memiliki keahlian forensik komputer sesuai dengan mekanisme yang berlaku.

\subsubsection{5}

\section{Melakukan Konfirmasi}

Auditor dapat melakukan konfirmasi yaitu mengajukan pertanyaan secara lisan atau tertulis kepada pihak ketiga mengenai suatu data atau informasi untuk meyakinkan kebenaran atas data atau informasi tersebut. 
Salah satu contoh pelaksanaan konfirmasi adalah pengiriman pertanyaan kepada kantor pabean negara importir mengenai jenis dan volume impor kayu dan hasil hutan dari Indonesia ke negara tersebut. Konfirmasi semacam ini dimaksudkan untuk mengetahui kebenaran data ekspor kayu dan hasil hutan dari Indonesia ke negara yang bersangkutan.

\subsubsection{6}

\section{Melaksanakan tinjauan analitikal}

Auditor dapat melakukan tinjauan analitikal dengan membandingkan angka-angka atau jumlah-jumlah yang terdapat di laporan keuangan atau laporan kegiatan untuk mengidentifikasi kemungkinan adanya kecurangan atau kejahatan.

Dalam bidang kehutanan, tinjauan analitikal dapat diterapkan misalnya untuk mengetahui kewajaran pembayaran DR dan PSDH dibandingkan dengan produksi kayu dan hasil hutan yang bersangkutan. Tinjauan analitikal semacam ini bisa dilaksanakan pada tingkat perusahaan ataupun untuk suatu daerah kabupaten atau kota atau propinsi tertentu.

\subsubsection{7} Melaksanakan Pengintaian

Pengintaian atau surveillance adalah pengamatan seksama secara terencana terhadap seseorang, suatu tempat atau obyek tertentu. Umumnya, pengintaian dilakukan terhadap orang. Jika auditor melakukan pengintaian terhadap suatu tempat atau obyek tertentu maka sesungguhnya pengintaian tersebut dilakukan dalam rangka pengintaian terhadap seseorang. Pengintaian umumnya dilaksanakan untuk mengetahui secara langsung kecurangan atau kejahatan yang dilakukan oleh seseorang.

Pengintaian bisa dilaksanakan oleh seseorang secara sendirian atau oleh beberapa orang sekaligus. Untuk pengintaian yang bergerak maka pengintaian bisa dilakukan dengan berjalan kaki atau menggunakan kendaraan. Pengintaian dapat dilakukan dengan bantuan perangkat tertentu, misalnya lensa dan kamera jarak jauh ataupun perangkat sistem posisi global (global positioning system/GPS). 
Untuk mengungkap kecurangan dan kejahatan di bidang kehutanan, pengintaian dapat dilaksanakan untuk mengetahui pergerakan kayu dan hasil hutan mulai dari pemanenan ke lokasi pengolahan sampai dengan ke pengguna lanjutannya.

\subsubsection{8}

\section{Melakukan Pengambilan Gambar atau Suara}

Auditor dapat melakukan pengambilan gambar dan suara dalam rangka memperkuat pembuktian dalam audit yang dilaksanakannya. Hasil pengambilan gambar dan suara dapat ditunjukkan kepada pihak-pihak lain yang berkepentingan dan memperkuat keterangan yang diberikan oleh auditor.

Pengambilan gambar dan suara dapat dilakukan dengan menggunakan perangkat foto dan perekam suara, baik yang mekanik maupun elektronik.

\section{Pendekatan dalam pelaksanaan audit}

Dalam melaksanakan audit investigatif maka auditor harus menerapkan pendekatan yang relatif berbeda dengan pendekatan yang dilaksanakan dalam audit non investigatif. Pendekatan yang dapat diterapkan dalam pelaksanaan audit investigatif adalah:

1. Auditor melaksanakan wawancara terhadap saksi yang mendukung audit dan menganalisa dokumen yang tersedia;

2. Auditor menggunakan bukti tidak langsung yang tersedia untuk meyakinkan saksi-saksi agar bisa mendapatkan bukti-bukti yang secara langsung menunjukkan terjadinya kecurangan atau kejahatan;

3. Jika sudah mendapatkan bukti-bukti yang cukup, auditor dapat mewawancarai orang atau orangorang yang diduga melakukan kecurangan atau kejahatan terutama untuk membuktikan adanya unsur niat atau kesengajaan.

\section{Chain of custody}

Dalam melaksanakan audit, auditor harus memperhatikan integritas bukti yang diperoleh dan menjaga kesinambungan penanganan (chain of custody) bukti-bukti yang diperoleh. Hal tersebut antara lain berarti bahwa:

1. Perolehan dokumen yang akan digunakan sebagai bukti audit dilaksanakan dengan dokumen resmi; 
2. Dokumen yang akan digunakan sebagai bukti audit tidak boleh dicoret-coret, atau diberi tanda tertentu. Coretan atau pemberian tanda-tanda tertentu hanya boleh dilakukan di sampul atau fotocopy dari dokumen yang akan digunakan sebagai bukti audit.

\section{Dokumentasi} audit
Auditor yang melaksanakan audit harus mendokumentasikan hasil auditnya di dalam kertas kerja audit. Kertas kerja ini akan direview oleh ketua tim dan penyelia audit dan dikumpulkan serta disusun secara sistematis di dalam suatu tempat penyimpanan dokumen.

\section{Penyelesaian} pelaksanaan audit
Jika auditor telah melaksanakan program kerja pemeriksaan yang diperlukan dan mengumpulkan buktibukti yang dapat menjawab seluruh pertanyaan $5 \mathrm{~W}+1 \mathrm{H}$ yang ada maka auditor dapat menghentikan audit dan menyusun Laporan Hasil Audit Investigatif.

\subsection{4}

\section{Penyusunan Laporan Hasil Audit}

Segera setelah selesai melaksanakan audit maka Ketua Tim Audit menyusun laporan audit investigatif. Laporan audit yang disusun harus memperhatikan ketentuan penyusunan laporan audit investigatif berikut ini.

1. Akurat dalam arti bahwa seluruh materi laporan misalnya menyangkut kecurangan atau kejahatan yang terjadi serta informasi penting lainnya, termasuk penyebutan nama, tempat atau tanggal adalah benar sesuai dengan bukti-bukti yang sudah dikumpulkan;

2. Jelas dalam arti bahwa laporan harus disampaikan secara sistematik dan setiap informasi yang disampaikan mempunyai hubungan yang logis. Sementara itu, istilah-istilah yang bersifat teknis harus dihindari dan kalau tidak bisa dihindari harus dijelaskan secara memadai;

3. Tidak memihak dalam arti bahwa laporan tidak mengandung bias atau prasangka dari auditor yang menyusun laporan atau pihak-pihak lain yang dapat mempengaruhi auditor. Laporan hanya memuat fakta-fakta dan tidak memuat opini atau pendapat pribadi auditor; 
4. Relevan dalam arti bahwa laporan hanya mengungkap informasi yang berkaitan langsung dengan kecurangan atau kejahatan yang terjadi;

5. Tepat waktu dalam arti bahwa laporan harus disusun segera setelah pekerjaan lapangan selesai dilaksanakan dan segera disampaikan kepada pihakpihak yang berkepentingan.

\section{$2.2 \quad$ Penelusuran Aliran Dana Hasil Kejahatan}

Penelusuran aliran dana hasil kejahatan merupakan suatu kegiatan yang dapat dilaksanakan auditor sebagai bagian dari audit investigatif atau bersamaan dengan pelaksanaan audit investigatif.

Tujuan penelusuran aliran dana hasil kejahatan
Penelusuran aliran dana hasil kejahatan dalam audit investigatif terutama bertujuan untuk mengetahui secara lebih mendalam kecurangan atau kejahatan yang terjadi. Penelusuran aliran dana hasil kejahatan, misalnya, dapat mengungkapkan adanya aliran dana ke pejabat negara atau penyelenggara negara tertentu yang memberikan izin, memberikan suatu persetujuan yang mendasari pemberian izin, melakukan pengawasan terhadap kegiatan di bidang kehutanan atau memberikan perlindungan keamanan terhadap suatu kawasan hutan atau jalur transportasi yang digunakan untuk memindahkan hasil hutan yang berasal dari suatu kejahatan.

Penelusuran aliran dana hasil kejahatan juga dapat mengungkapkan pihak-pihak yang merencanakan, memerintahkan atau membiayai kecurangan atau kejahatan yang terjadi. Pada umumnya, dana hasil kejahatan akan mengalir kepada pelaku dan mereka yang membantu melakukan kecurangan atau kejahatan.

Secara umum, kewenangan yang dimiliki Auditor untuk menelusuri aliran hasil kejahatan relatif terbatas. Auditor memiliki sejumlah keterbatasan untuk mengakses data dan informasi yang berkaitan dengan transaksi keuangan yang dimiliki perseorangan atau korporasi yang diduga melakukan kecurangan atau kejahatan. Menurut hukum positif yang berlaku di Indonesia, penelusuran aliran dana yang tersimpan di perbankan hanya dapat dilakukan 
oleh pejabat pajak, polisi, jaksa atau hakim. Berdasarkan izin dari Gubernur Bank Indonesia (ps 41 dan 42 UU No.10/1998 tentang Perbankan), kecuali untuk tindak pidana pencucian uang penyidik, penuntut umum dan hakim dapat meminta keterangan tentang harta kekayaan seseorang kepada PJK (Penyedia Jasa Keuangan = Bank) tanpa memerlukan izin dari Gubernur Bank Indonesia. Sedangkan untuk auditor yang berasal dari BPK/BPKP dapat meminta penelusuran harta kekayaan seseorang kepada PJK melalui PPATK dalam bentuk permintaan informasi sebagaimana dimaksud dalam Peraturan Kepala PPATK nomor: PER-09/ 1.02.1/ 11/ 2009, tanggal 10 Nopember 2009 tentang Tata Cara Pertukaran Informasi.

\section{Teknik penelusuran}

Teknik yang digunakan dalam penelusuran dana hasil kejahatan pada dasarnya sama dengan teknik yang digunakan dalam audit investigatif. Dalam kenyataannya, Auditor akan mengkombinasikan beberapa teknik yang digunakan dalam audit investigatif untuk menelusuri aliran dana hasil kejahatan. Auditor, misalnya akan mengumpulkan data dan informasi yang berkaitan dengan transaksi keuangan dan menganalis data dan informasi tersebut serta melakukan wawancara dengan pihak-pihak yang diduga mengetahui data dan informasi yang telah dianalisis.

Mekanisme penelusuran dana hasil kejahatan akan sangat bergantung kepada indikasi kecurangan atau kejahatan yang sesungguhnya terjadi. Namun demikian, untuk memberikan gambaran mengenai mekanisme penelusuran aliran dana hasil kejahatan maka pada bagian berikut ini akan disajikan suatu mekanisme penelusuran aliran dana hasil kejahatan di bidang kehutanan yang mungkin dilaksanakan.

1. Lakukan analisis terhadap proses bisnis atau kegiatan yang dilakukan orang atau korporasi pelaku kejahatan dan teliti kemungkinan adanya tindak pidana korupsi. Jika dugaan kejahatan yang dilakukan oleh pelaku kejahatan berkaitan dengan perizinan maka teliti proses pemberian izin dan identifikasi dugaan tindak pidana korupsi yang mungkin terjadi serta pejabat negara atau penyelenggara negara yang mempunyai peranan penting dalam proses pemberian izin yang mungkin terlibat. Jika dugaan kejahatan yang dilakukan oleh 
pelaku kejahatan berkaitan dengan pengawasan kegiatan usaha di bidang kehutanan maka teliti proses pengawasan yang ada dan identifikasi dugaan tindak pidana korupsi yang mungkin terjadi serta pejabat negara atau penyelenggara negara yang mempunyai peranan penting dalam proses pengawasan tersebut yang mungkin terlibat.

2. Dapatkan seluruh dokumen yang berkaitan dengan transaksi keuangan, baik dokumen dalam bentuk tercetak ataupun dalam bentuk data elektronik misalnya dokumen pembukuan, salinan rekening bank, buku tabungan, cek dan bonggol cek (bagian cek yang tertinggal di nasabah), dan bukti-bukti pendukung transaksi keuangan.

3. Lakukan analisis terhadap dokumen-dokumen transaksi keuangan dan teliti kemungkinan adanya transaksi yang mencurigakan, misalnya pengeluaran uang tunai atau transfer dalam jumlah besar yang tidak disertai dengan bukti pendukung yang memadai.

4. Jika teridentifikasi adanya transaksi keuangan yang mencurigakan, maka untuk auditor pemerintah (BPK, BPKP) dapat segera meminta bantuan kepada PPATK untuk menelusuri aliran dana atas nama orang yang dicurigai tersebut berikut keluarganya guna mengungkap aliran dana atau transaksi, baik melalui penelusuran mundur (transaksi sebelumnya) maupun transaksi maju ke (transaksi berikutnya). Jika terdapat transaksi keuangan yang mengalir ke perseorangan atau korporasi yang lain maka Auditor harus berupaya untuk mendapatkan dokumen transaksi tersebut dari pihak-pihak yang bersangkutan secara langsung yang diberikan secara sukarela oleh yang bersangkutan. Dalam hal transaksi dilakukan melalui perbankan atau pihak ketiga maka auditor harus berupaya untuk mendapatkan data tersebut dari pihak perbankan atau pihak ketiga yang bersangkutan.

5. Jika sudah mendapat gambaran mengenai aliran dana hasil kejahatan, susun skema aliran dana hasil kejahatan dan kumpulkan bukti-bukti pendukung, baik dalam bentuk dokumen atau berita acara hasil wawancara. 
Setelah mengetahui aliran dana hasil kejahatan dan mengumpulkan bukti-bukti yang mendukung maka Auditor dapat mengintegrasikan fakta-fakta yang diperoleh dari penelusuran aliran dana hasil kejahatan ke dalam laporan hasil audit investigatif atau menyampaikan fakta-fakta tersebut kepada penyelidik dan penyidik agar penyelidik dan penyidik dapat melakukan tindakan yang diperlukan.

Dalam melaksanakan penelusuran dana hasil kejahatan, beberapa hal yang perlu diperhatikan oleh PPATK adalah sebagai berikut:

1. Pelaku kejahatan akan selalu berupaya untuk menyamarkan atau menyembunyikan hasil kejahatan sehingga transaksi keuangan tidak mudah ditelusuri misalnya dengan membuat transaksi aliran dana hasil kejahatan seolah-olah serupa dengan transaksi usaha yang normal atau transaksi aliran dana hasil kejahatan dilaksanakan secara berlapis atau berputar sebelum dikirimkan kepada penerima aliran dana yang sesungguhnya.

2. Penerima aliran dana yang sesungguhnya juga dapat menggunakan orang lain untuk menerima dana hasil kejahatan. Mereka bisa mengatasnamakan penerimaan dana hasil kejahatan kepada keluarga yang bersangkutan misalnya suami atau istri, anak, adik atau kakak, atau orang tua. Selain itu, mereka juga bisa mengatasnamakan penerimaan dana hasil kejahatan kepada orang lain yang tidak mempunyai hubungan kekeluargaan. Dana hasil kejahatan juga bisa dialirkan melalui organisasi tertentu, misalnya lembaga pendidikan, lembaga sosial atau kegiatan usaha tertentu.

Beberapa hal yang harus dipahami oleh seorang Auditor adalah:

1. Pelaku kejahatan juga dapat menyusun pencatatan ganda atas transaksi keuangan untuk kepentingan yang berbeda. Pelaku kejahatan, misalnya, menyusun suatu pencatatan transaksi yang dimanipulasi untuk kepentingan pelaporan kepada pemerintah, atau kalangan perbankan, dan menyusun pencatatan yang sebenarnya untuk kepentingan internal pelaku kejahatan. 
2. Tipologi atau bentuk-bentuk umum pencucian uang pada kejahatan di bidang kehutanan untuk lebih memudahkan pengidentifikasian aliran dana hasil kejahatan di bidang kehutanan. 


\section{Referensi}

Association of Certified Fraud Examiners 2006 Fraud Examiners Manual. http://www.acfe.com/

Badan Pemeriksa Keuangan 2007 Peraturan Badan Pemeriksa Keuangan Republik Indonesia Nomor 1 Tahun 2007 tentang Standar Pemeriksaan Keuangan Negara. http://www.bpk.go.id/spkn/spkn.pdf [diakses 11 Maret 2011].

Departemen Kehutanan 2007 Eksekutif Data Strategis Kehutanan 2007 Badan Planologi Kehutanan, Departemen Kehutanan, Jakarta. http://www.dephut. go.id/Halaman/Buku-buku/2007/strategis07/17.pdf [diakses 20 Februari 2011].

Food and Agricultural Organization of the United Nations 2001 Global Forest Resources Assessment 2000. http://www.fao.org/docrep/003/y0900e/ y0900e04.htm.

Komisi Pemberantasan Korupsi 2006 Memahami untuk Membasmi: Buku Panduan untuk Memahami Tindak Pidana Korupsi. http://www.kpk.go.id/modules/news/ index.php?storytopic $=12$.

Pusat Pelaporan dan Analisis Transaksi Keuangan 2003 Pedoman Umum Pencegahan dan Pemberantasan Tindak Pidana Pencucian Uang bagi Penyedia Jasa Keuangan, Edisi Pertama. http://www.ppatk.go.id/content.php?s_sid=35. 



\section{Lampiran 1}

\section{Audit Investigatif: Kasus Hipotetik Korupsi di Bidang Kehutanan}

\begin{tabular}{|c|}
\hline $\begin{array}{l}\text { Korupsi: Pemberian Izin Usaha Perkebunan yang } \\
\text { Tidak Sesuai Ketentuan Mengakibatkan Kerugian } \\
\text { Negara karena Kerusakan Hutan }\end{array}$ \\
\hline $\begin{array}{l}\text { Kasus yang disajikan di bawah ini adalah kasus } \\
\text { hipotetik. Kasus ini berdasar kepada kasus tindak pidana } \\
\text { korupsi yang sesungguhnya yang sudah diputus oleh } \\
\text { pengadilan dan sudah mempunyai kekuatan hukum } \\
\text { yang tetap. Kasus hipotetik tidak menggambarkan } \\
\text { kronologis kejahatan yang sesungguhnya tetapi } \\
\text { sebagian besar didasarkan kepada data dan informasi } \\
\text { yang nyata. Reka ulang dimaksudkan untuk memberikan } \\
\text { gambaran mengenai penerapan audit investigatif } \\
\text { terhadap bentuk kejahatan seperti ini. }\end{array}$ \\
\hline $\begin{array}{l}\text { Pengumpulan Data dan Informasi serta Analisis } \\
\text { Kemungkinan Adanya Korupsi di Bidang } \\
\text { Kehutanan }\end{array}$ \\
\hline $\begin{array}{l}\text { Pada tahun 2006, auditor mengumpulkan citra satelit } \\
\text { untuk kawasan hutan di provinsi KT mulai tahun } \\
2000 \text { sampai dengan } 2002 \text { dan mendapatkan adanya } \\
\text { deforestasi pada sejumlah kawasan hutan di Kabupaten } \\
\text { BL, BR dan NK di provinsi tersebut. }\end{array}$ \\
\hline $\begin{array}{l}\text { Auditor mengumpulkan data dan informasi tambahan } \\
\text { untuk mengetahui pihak-pihak yang kemungkinan } \\
\text { bertanggung jawab atas deforestasi tersebut. Untuk } \\
\text { itu, Auditor mengumpulkan data dan informasi untuk } \\
\text { mengidentifikasi institusi atau korporasi yang memiliki } \\
\text { konsesi atau hak atas tanah pada kawasan hutan yang } \\
\text { mengalami deforestasi. Data dan informasi dicari melalui: } \\
\text { 1. Kantor Wilayah dan Kantor Dinas Kehutanan Provinsi } \\
\text { KT dan Kabupaten BL, BR dan NK; } \\
\text { 2. Kantor Badan Pertanahan Provinsi KT dan Kabupaten } \\
\text { BL, BR dan NK; }\end{array}$ \\
\hline
\end{tabular}


Dari Kantor Wilayah dan Kantor Dinas Kehutanan serta Kantor Badan Pertanahan Nasional, Auditor menemukan adanya sebelas perusahaan yang memiliki izin usaha perkebunan pada kawasan hutan yang mengalami deforestasi. Nama perusahaan dan luas konsesi perkebunan masing-masing adalah sebagai berikut.
1. PT BPM
18.000 ha
2. $\mathrm{PT} K B S$
30.000 ha
3. $\mathrm{PT} M C A$
20.000 ha
4. PTBSI
20.000 ha
5. PTTMSJ
9.900 ha
6. $\mathrm{PT}$ SBP
20.000 ha
7. $\mathrm{PT} B \mathrm{BAJ}$
17.700 ha
8. PTRBU
20.000 ha
9. $\mathrm{PT}$ BHP
6.000 ha
10. PT BBS
20.000 ha
11. PT BSP
19.250 ha

Luas keseluruhan dari perkebunan tersebut adalah 200.850 ha. Izin usaha perkebunan tersebut di atas diberikan mulai dari tahun 1999 sampai dengan 2002.

Auditor mengumpulkan data dan informasi izin usaha perkebunan bagi perusahaan-perusahaan tersebut. Pada saat yang sama, auditor juga mengumpulkan peraturanperaturan yang berkaitan dengan perizinan yang berlaku bagi kegiatan usaha perkebunan.

Dari analisis yang dilakukan, Auditor mendapatkan bukti bahwa alamat para pemegang saham dari perusahaanperusahaan tersebut menunjuk ke satu alamat yang sama. Pemeriksaan lebih lanjut menunjukkan bahwa alamat tersebut adalah alamat kantor dari kelompok usaha SDG. Auditor menduga bahwa perusahaanperusahaan tersebut adalah 'perusahaan boneka' yang sengaja dibentuk untuk menyiasati ketentuan dalam Surat Keputusan Menteri Kehutanan dan Perkebunan No. 107/Kpts-II/1999 tanggal 3 Maret 1999 tentang Perizinan Usaha Perkebunan. Dalam ketentuan tersebut, setiap perusahaan atau kelompok perusahaan dalam satu provinsi tidak boleh memiliki lahan perkebunan lebih dari 20.000 hektar. 
Sampai dengan saat pelaksanaan audit pada tahun 2006, dari analisis lebih lanjut terhadap citra satelit, perusahaan-perusahaan tersebut tidak serius mengusahakan perkebunan sesuai dengan izin yang diberikan. Sampai dengan Juni 2006, perusahaanperusahaan tersebut telah melakukan penebangan dalam kawasan hutan seluas sekitar 53.600 hektar tetapi baru merealisasikan perkebunan sawit seluas sekitar 2.170 hektar.

Berdasarkan data dan informasi yang ada, Auditor meyakini adanya kejahatan yang mengakibatkan deforestasi. Auditor meyakini adanya predikasi atau alasan yang cukup kuat untuk memulai suatu audit investigatif.

\section{Penyusunan Hipotesis dan Rencana Audit Investigatif}

Sebelum mulai melaksanakan audit investigatif maka Auditor perlu menyusun rencana audit. Agar perencanaan audit investigatif lebih terarah maka Auditor perlu menyusun suatu hipotesis atau dugaan sementara mengenai kejahatan yang telah terjadi. Penyusunan hipotesis memungkinkan Auditor menyusun program kerja yang lebih terfokus yaitu terarah kepada pembuktian hipotesis yang telah disusun. Auditor tidak perlu mengumpulkan data dan informasi tambahan yang tidak mengarah kepada pembuktian hipotesis yang telah disusun.

Pendekatan yang bisa dilakukan untuk menyusun dugaan sementara mengenai kejahatan yang telah terjadi adalah dengan mengembangkan pertanyaanpertanyaan $5 \mathrm{~W}$ dan $1 \mathrm{H}$ berikut:

1. Who: siapa pelaku kejahatan

2. What: apa kejahatan yang telah dilakukan

3. When: kapan atau dalam periode waktu mana kejahatan dilakukan

4. Where: dimana lokasi terjadinya kejahatan

5. Why: mengapa pelaku melakukan kejahatan

6. How: bagaimana pelaku melakukan kejahatan 
Berdasarkan analisis yang sudah dilakukan maka Auditor menyusun hipotesis sebagai berikut.

Selama periode 1999 sampai dengan 2006 direksi SDG secara melawan hukum mengajukan dan menerima izin usaha perkebunan dan berdasarkan izin tersebut melakukan penebangan di kawasan hutan tetapi tidak melaksanakan usaha perkebunan sesuai izin yang diberikan sehingga mengakibatkan kerugian negara setidaknya sebesar nilai tegakan di kawasan hutan yang telah ditebang di Kabupaten BL, BR dan NK di Provinsi KT.

Who: direksi SDG

What: secara melawan hukum mengajukan dan menerima izin usaha perkebunan, melakukan penebangan di kawasan hutan, tidak melaksanakan usaha perkebunan

When: dalam periode 1999 sampai dengan 2006 Where: di Kabupaten BL, BR dan NK di Provinsi KT Why: ?

How: ?

Dari hipotesis yang telah disusun maka Auditor menyusun rencana audit investigatif antara lain program kerja audit yang mengarah kepada 4 fokus kegiatan utama yaitu:

1. telusuri proses pemberian izin usaha perkebunan dan penebangan di kawasan hutan dan dapatkan dokumen yang berkaitan serta identifikasi setiap pelanggaran terhadap ketentuan yang berlaku;

2. lakukan observasi lapangan ke kawasan hutan yang terdeforestasi dan dapatkan keterangan ahli yang diperlukan serta hitung perkiraan besarnya kerugian negara;

3. identifikasi pihak-pihak yang diduga terlibat dan identifikasi kemungkinan adanya transaksi keuangan di antara mereka.

4. lakukan wawancara dengan pihak-pihak yang diduga terlibat. 
Penelusuran proses pemberian izin usaha perkebunan dan penebangan di kawasan hutan menghasilkan temuan sebagai berikut:

1. Permohonan dan pemberian Izin Usaha Perkebunan kepada perusahaan-perusahaan dalam kelompok usaha SDG tidak sesuai ketentuan yaitu keseluruhan luasnya melebihi batas maksimum pemberian izin usaha perkebunan kepada satu kelompok usaha di dalam satu provinsi yaitu seluas 20.000 hektar.

2. Permohonan dan pemberian Izin Pemanfaatan Kayu (IPK) kepada perusahaan-perusahaan dalam kelompok usaha SDG tidak sesuai dengan ketentuan Kepmenhutbun No. 538 tahun 1999 yaitu:

- Pemberian izin kepada beberapa perusahaan diberikan oleh Gubernur KT pada saat itu, yang tidak memiliki kewenangan untuk itu;

- Belum ada Surat Persetujuan Prinsip Pelepasan Kawasan Hutan dari Menhutbun kecuali pada areal KBNK yang tidak dibebani hak yang tidak diperlukan surat pelepasan kawasan dari Menhutbun.

- Pengajuan permohonan dikirimkan langsung kepada Dirjen PHP tanpa melalui Kakanwil Kehutanan KT;

- Pemohon tidak melampirkan Surat Persetujuan Prinsip Pelepasan Kawasan Hutan dari Menhutbun;

- Pemohon tidak melampirkan feasibility study atau studi kelayakan;

- Tidak ada bukti tata batas areal yang dilepaskan atau areal yang dicadangkan;

- Pemohon tidak menyerahkan jaminan bank garansi PSDH-DR;

- Belum dilakukan kegiatan inventarisasi awal (timber cruising) untuk mengetahui potensi tegakan;

- Belum dilakukan pemeriksaan kemampuan teknis dan manajemen perusahaan pemohon IPK serta rencana dan realisasi pembangunan non kehutanan pada areal yang dimohon IPK;

- Pemberian persetujuan prinsip IPK tidak diprioritaskan kepada pemegang $\mathrm{HPH}$. 
Observasi lapangan ke kawasan hutan yang terdeforestasi menghasilkan temuan bahwa kawasan hutan tersebut memang telah mengalami kerusakan karena adanya penebangan.

Secara keseluruhan luas kawasan hutan yang telah ditebang dari tahun 1999 sampai dengan 2006 adalah 23.600 hektar dengan perkiraan jumlah kayu tebangan sebesar $697.260 \mathrm{~m}^{3}$ dengan nilai Rp 346.823.970.564,24 yang merupakan kerugian negara.

Wawancara dengan pihak-pihak yang terlibat antara lain menghasilkan pengakuan sebagai berikut:

1. HKP, President of Board of Director SDG, menyatakan bahwa perusahaan-perusahaan yang memperoleh izin usaha perkebunan dan izin pemanfaatan kayu adalah perusahaan-perusahaan yang termasuk dalam kelompok usaha SDG.

2. ASF, Gubernur KT menyatakan bahwa pemberian izin perkebunan adalah dalam rangka program pengembangan kebun sawit sejuta hektar dan mengakui bahwa program tersebut belum pernah mendapat persetujuan dari DPRD KT.

3. ASF, Gubernur KT menyatakan bahwa dia tidak mengetahui kalau perusahaan-perusahaan yang memperoleh izin usaha perkebunan dan izin pemanfaatan kayu adalah perusahaan-perusahaan yang termasuk dalam kelompok usaha SDG.

4. AYU, mantan Kakanwil Dephutbun KT menyatakan bahwa dia telah mengeluarkan izin pemanfaatan kayu kepada perusahaan-perusahaan yang termasuk dalam kelompok usaha SDG untuk memenuhi permintaan ASF meskipun beberapa persyaratan untuk pemberian izin tersebut belum terpenuhi.

5. NBR, mantan Plt. Kakanwil Dephutbun KT dan Kadis Kehutanan KT menyatakan bahwa dia telah menyetujui dan tetap menerbitkan IPK walaupun selaku pejabat teknis dia mengetahui bahwa permohonan IPK tersebut tidak memenuhi persyaratan.

6. SYW selaku Dirjen PHP menyatakan bahwa dia telah menerbitkan persetujuan prinsip IPK kepada perusahaan-perusahaan yang termasuk dalam kelompok usaha SDG. 
Berdasarkan pemeriksaan investigatif yang dilaksanakan, Auditor telah mengidentifikasi pihak-pihak yang terlibat yang antara lain terdiri dari:

1. HKP, President Board of Director SDG

2. ASF, Gubernur KT;

3. AYU, mantan Kakanwil Dephutbun KT;

4. NBR, mantan PIt. Kakanwil Dephutbun KT dan Kadis Kehutanan KT;

5. SYW, mantan Dirjen PHP Departemen Kehutanan.

Penelusuran untuk mengidentifikasi transaksi keuangan antara pihak-pihak yang terlibat tidak dapat dilakukan karena terbatasnya akses informasi auditor mengenai hal tersebut.

Berdasarkan audit investigatif yang telah dilaksanakan, Auditor berkesimpulan bahwa terdapat bukti permulaan yang cukup yang dapat dijadikan sebagai dasar untuk mengusulkan penyelidikan tindak pidana korupsi terhadap pemberian izin usaha perkebunan dan izin pemanfaatan kayu yang telah diberikan kepada perusahaan-perusahaan yang termasuk dalam kelompok usaha SDG. 


\section{Lampiran 2}

\section{Pedoman Pelaksanaan Observasi Lapangan untuk Membuktikan Adanya Deforestasi atau Degradasi}

1. Pemanfaatan teknologi Sistem Informasi Geografis

(Geographical Information System/GIS) memungkinkan auditor atau penyelidik untuk mengidentifikasi adanya indikasi deforestasi atau degradasi di suatu kawasan hutan. Namun demikian, untuk membuktikan indikasi tersebut auditor atau penyelidik perlu melaksanakan observasi langsung ke lapangan untuk menyaksikan secara langsung dan mendokumentasikan kondisi yang sesungguhnya ada di lapangan.

2. Observasi lapangan dilaksanakan dengan bantuan peralatan sebagai berikut.

1. Perangkat GPS (Global positioning system)

2. Kamera foto atau kamera video

3. Kompas

3. Dalam mendokumentasikan hasil observasi lapangan, auditor dan penyelidik harus menjaga kesinambungan penanganan dokumen hasil observasi lapangan (chain of custody). Hal tersebut, antara lain, berarti bahwa:

a. Auditor atau penyelidik harus membuat suatu berita acara pelaksanaan observasi lapangan yang menjelaskan mengenai kegiatan yang dilaksanakan dan hasil yang diperoleh.

b. Dokumen yang dihasilkan dari observasi di lapangan, baik dalam bentuk data digital maupun analog tidak boleh diubah dan jika ada kebutuhan untuk melaksanakan analisis dengan menggunakan 
dokumen tersebut maka auditor atau penyelidik membuat suatu dokumen turunan untuk kepentingan analisis.

c. Auditor atau penyelidik harus membuat suatu berita acara jika terjadi perpindahan penguasaan dokumen hasil observasi lapangan.

4. Untuk mendapatkan hasil yang optimal maka titik-titik observasi harus ditentukan dengan baik, misalnya di titiktitik tertinggi yang memungkinkan perolehan gambar yang terbuka dengan area yang luas.

5. Untuk membuktikan deforestasi atau degradasi pada suatu area maka paling sedikit diperlukan observasi di dua titik yang berbeda pada area yang citra satelitnya memiliki karakteristik atau warna yang sama.

6. Dalam melaksanakan observasi lapangan, auditor atau penyelidik perlu mengidentifikasi risiko-risiko yang mungkin ada dan mempersiapkan diri untuk menghadapi risiko-risiko yang sudah teridentifikasi tersebut.

\section{Bagian 2 Prosedur Observasi Lapangan}

\section{Bagian 2.1}

\section{Prosedur Persiapan Observasi Lapangan}

1. Berdasarkan peta area yang akan diobservasi, tentukan titik-titik koordinat yang dipilih untuk observasi lapangan.

2. Siapkan peralatan yang akan digunakan serta peralatan penunjang dan perbekalan yang diperlukan untuk menuju ke titik-titik observasi lapangan.

1. Pastikan titik observasi di lapangan telah sesuai dengan titik observasi yang ditetapkan dengan melihat posisi koordinat di perangkat GPS.

2. Ambil foto atau gambar perangkat GPS sedemikian rupa sehingga bisa menunjukkan dan mendokumentasikan koordinat titik observasi di lapangan.

3. Ambil foto atau gambar kawasan hutan yang diobservasi sedikitnya dari 4 (empat) arah, yaitu timur, selatan, barat dan utara.

4. Buat berita acara observasi lapangan. 
Bagian 2.3

\section{Prosedur Penyimpanan dan Penggunaan Dokumen Hasil Observasi Lapangan}

1. Pindahkan dokumen yang dihasilkan dari kamera foto atau video ke dalam media penyimpanan yang tersedia. Untuk dokumen digital misalnya dapat disimpan ke dalam hard disk, CD-ROM atau DVDROM.

2. Cetak atau proses dokumen yang dihasilkan dan buat daftar foto/video serta satukan daftar foto/ video dan dokumen yang dihasilkan dengan berita acara observasi lapangan.

3. Jika foto/video tertentu diperlukan untuk kepentingan analisis maka buat dokumen turunan dan gunakan dokumen turunan tersebut untuk kepentingan analisis.

4. Jika foto/video tertentu perlu dikirimkan untuk kepentingan pihak lain maka buat dokumen turunan dan gunakan dokumen turunan untuk kepentingan tersebut. 


\section{Lampiran 3}

\section{Contoh Prosedur Audit Investigatif}

\section{Susun Peta Deforestasi pada Periode yang Diaudit}

1. Dapatkan citra satelit untuk area yang akan dianalisis.

2. Dapatkan data-data yang akan yang akan disusun sebagai data geo-spasial tambahan misalnya datadata mengenai batas kawasan hutan berdasar peta tata ruang, batas konsesi usaha baik untuk usaha kehutanan maupun non kehutanan.

3. Dengan menggunakan teknologi GIS, susun peta perkembangan deforestasi dari tahun ke tahun selama periode yang diaudit atau diselidiki.

4. Tentukan sedikitnya tiga wilayah kabupaten dalam satu provinsi dengan tingkat deforestasi terbesar yang akan dianalisis lebih lanjut.

\section{Lakukan Analisis Penyebab Deforestasi sesuai dengan Tipologi Korupsi dalam Sektor Kehutanan}

1. Berdasarkan data yang tersedia teliti kemungkinan adanya pelanggaran ketentuan dalam penetapan tata ruang serta pemberian izin alih fungsi dan pengusahaan hutan.

2. Berdasarkan data yang tersedia teliti kemungkinan adanya kelemahan dalam pengawasan terhadap kegiatan pengusahaan hutan mulai dari inventarisasi potensi tegakan hutan awal (cruising), penetapan DR dan PSDH, penebangan, pengangkutan dan pengangkutan antar pulau sampai dengan ekspor.

3. Berdasarkan data yang tersedia teliti kemungkinan adanya industri pengolahan hasil hutan yang tidak didukung oleh pasokan yang berasal dari pengelolaan hutan secara lestari. 


\section{Kumpulkan Informasi Mengenai Politically Exposed Person (PEP) dan Profil Perusahaan}

1. Dapatkan nama-nama pejabat penting pemerintah, baik dari pemerintah pusat maupun daerah, aparat penegak hukum dan militer yang terlibat dalam proses di sektor kehutanan dan jika memungkinkan termasuk juga data keluarganya.

2. Dapatkan nama-nama orang-orang dari sektor non pemerintah yang dapat mempengaruhi pejabat penting pemerintah.

3. Susun Profil Perusahaan yang diduga terlibat dalam kejahatan kehutanan, khususnya perusahaanperusahaan yang diduga mempunyai keterkaitan dengan deforestasi.

\section{Kumpulkan Informasi Umum dari Masyarakat dan \\ Media}

1. Kumpulkan informasi dari lembaga swadaya masyarakat, dari pusat dokumentasi media dan dari internet atau sumber-sumber informasi lain mengenai informasi-informasi yang berkaitan dengan permasalahan yang diaudit atau diselidiki.

\section{Lakukan Observasi Lapangan}

1. Laksanakan persiapan observasi lapangan antara lain dengan menentukan titik-titik koordinat yang dipilih untuk observasi lapangan serta menyiapkan peralatan dan perbekalan yang diperlukan.

2. Laksanakan observasi lapangan dengan mengambil beberapa foto atau video dari lokasi yang ditentukan dan buat berita acara observasi lapangan.

3. Gunakan data dan informasi yang diperoleh dari observasi lapangan untuk analisis lanjutan. 


\section{Susun Indikasi Kecurangan atau Kejahatan}

1. Jika hasil analisis dan pengumpulan informasi yang ada menunjukkan adanya indikasi tindak pidana korupsi maka susun hipotesis atau dugaan tindak pidana yang mungkin dilakukan.

2. Jika diperlukan, laksanakan audit atau penyelidikan tambahan untuk mengumpulkan informasi yang diperlukan.

3. Jika audit atau penyelidikan tidak dilaksanakan oleh auditor pemerintah atau aparat penegak hukum maka sampaikan indikasi tindak pidana kepada auditor dan aparat penegak hukum untuk dilakukan tindakan lanjutan berupa audit investigasi atau penyelidikan. 


\section{Lampiran 4}

\section{Bentuk-bentuk Tindak Pidana Kehutanan dan Ancaman Pidananya Sesuai Undang- Undang Nomor 41 Tahun 1999 tentang Kehutanan}

Sumber: http://www.dephut.go.id/index.php?q=id/node/247

Merusak prasarana dan sarana perlindungan hutan

\section{Pasal 50 ayat (1)}

Setiap orang dilarang merusak prasarana dan sarana perlindungan hutan.

Pasal 78 ayat (1)

Barang siapa dengan sengaja melanggar ketentuan sebagaimana dimaksud dalam Pasal 50 ayat (1) atau Pasal 50 ayat (2), diancam dengan pidana penjara paling lama 10 (sepuluh) tahun dan denda paling banyak Rp 5.000.000.000,00 (lima milyar rupiah).
Melakukan kegiatan yang menimbulkan kerusakan hutan

\section{Pasal 50 ayat (2)}

Setiap orang yang diberikan izin usaha pemanfaatan kawasan, izin usaha pemanfaatan jasa lingkungan, izin usaha pemanfaatan hasil hutan kayu dan bukan kayu, serta izin pemungutan hasil hutan kayu dan bukan kayu, dilarang melakukan kegiatan yang menimbulkan kerusakan hutan.

Pasal 78 ayat (1)

Barang siapa dengan sengaja melanggar ketentuan sebagaimana dimaksud dalam Pasal 50 ayat (1) atau Pasal 50 ayat (2), diancam dengan pidana penjara paling lama 10 (sepuluh) tahun dan denda paling banyak Rp 5.000.000.000,00 (lima milyar rupiah). 


Mengerjakan
dan atau
menggunakan dan
atau menduduki
kawasan hutan
secara tidak sah

Mengerjakan

dan atau

menggunakan dan

kawasan hutan

secara tidak sah

\section{Pasal 50 ayat (3) huruf a}

Setiap orang dilarang mengerjakan dan atau

menggunakan dan atau menduduki kawasan hutan

secara tidak sah;

\section{Pasal 78 ayat (2)}

Barang siapa dengan sengaja melanggar ketentuan sebagaimana dimaksud dalam Pasal 50 ayat (3) huruf a, huruf b, atau huruf c, diancam dengan pidana penjara paling lama 10 (sepuluh) tahun dan denda paling banyak Rp. 5.000.000.000,00 (lima milyar rupiah).
Merambah kawasan hutan

\section{Pasal 50 (3) huruf b}

Setiap orang dilarang merambah kawasan hutan;

\section{Pasal 78 ayat (2)}

Barang siapa dengan sengaja melanggar ketentuan sebagaimana dimaksud dalam Pasal 50 ayat (3) huruf a, huruf $b$, atau huruf $c$, diancam dengan pidana penjara paling lama 10 (sepuluh) tahun dan denda paling banyak Rp. 5.000.000.000,00 (lima milyar rupiah).

\section{Melakukan penebangan pohon dalam kawasan hutan dengan radius atau jarak tertentu}

\section{Pasal 50 ayat (3) huruf c}

Setiap orang dilarang melakukan penebangan pohon dalam kawasan hutan dengan radius atau jarak sampai dengan:

1. 500 (lima ratus) meter dari tepi waduk atau danau;

2. 200 (dua ratus) meter dari tepi mata air dan kiri kanan sungai di daerah rawa;

3. 100 (seratus) meter dari kiri kanan tepi sungai;

4. 50 (lima puluh) meter dari kiri kanan tepi anak sungai;

5. 2 (dua) kali kedalaman jurang dari tepi jurang;

6. 130 (seratus tiga puluh) kali selisih pasang tertinggi dan pasang terendah dari tepi pantai.

\section{Pasal 78 ayat (2)}

Barang siapa dengan sengaja melanggar ketentuan sebagaimana dimaksud dalam Pasal 50 ayat (3) huruf a, huruf $b$, atau huruf $c$, diancam dengan pidana penjara paling lama 10 (sepuluh) tahun dan denda paling banyak Rp. 5.000.000.000,00 (lima milyar rupiah). 
Membakar hutan

\section{Pasal 50 (3) huruf d}

Setiap orang dilarang membakar hutan;

\section{Pasal 78 ayat (3)}

Barang siapa dengan sengaja melanggar ketentuan sebagaimana dimaksud dalam Pasal 50 ayat (3) huruf d, diancam dengan pidana penjara paling lama 15 (lima belas) tahun dan denda paling banyak Rp. 5.000.000.000,00 (lima milyar rupiah).

\section{Pasal 78 ayat (4)}

Barang siapa karena kelalaiannya melanggar ketentuan sebagaimana dimaksud dalam Pasal 50 ayat (3) huruf d, diancam dengan pidana penjara paling lama 5 (lima) tahun dan denda paling banyak Rp. 1.500.000.000,00 (satu milyar lima ratus juta rupiah).
Menebang pohon atau memanen atau memungut hasil hutan di dalam hutan tanpa memiliki hak atau izin

\section{Pasal 50 ayat (3) huruf e}

Setiap orang dilarang menebang pohon atau memanen atau memungut hasil hutan di dalam hutan tanpa memiliki hak atau izin dari pejabat yang berwenang;

\section{Pasal 78 ayat (5)}

Barang siapa dengan sengaja melanggar ketentuan sebagaimana dimaksud dalam Pasal 50 ayat (3) huruf e atau huruf $f$, diancam dengan pidana penjara paling lama 10 (sepuluh) tahun dan denda paling banyak Rp. 5.000.000.000,00 (lima milyar rupiah).

\section{Pasal 50 ayat (3) huruf $f$}

Setiap orang dilarang menerima, membeli atau menjual, menerima tukar, menerima titipan, menyimpan, atau memiliki hasil hutan yang diketahui atau patut diduga berasal dari kawasan hutan yang diambil atau dipungut secara tidak sah;

\section{Pasal 78 ayat (5)}

Barang siapa dengan sengaja melanggar ketentuan sebagaimana dimaksud dalam Pasal 50 ayat (3) huruf e atau huruff, diancam dengan pidana penjara paling lama 10 (sepuluh) tahun dan denda paling banyak Rp. 5.000.000.000,00 (lima milyar rupiah). 
Melakukan

kegiatan

penyelidikan

umum atau

eksplorasi atau

eksploitasi bahan

tambang tanpa

izin

\section{Pasal 50 ayat (3) huruf $\mathrm{g}$}

Setiap orang dilarang melakukan kegiatan penyelidikan umum atau eksplorasi atau eksploitasi bahan tambang di dalam kawasan hutan, tanpa izin Menteri;

\section{Pasal 78 ayat (6)}

Barang siapa dengan sengaja melanggar ketentuan sebagaimana dimaksud dalam Pasal 38 ayat (4) atau Pasal 50 ayat (3) huruf g, diancam dengan pidana penjara paling lama 10 (sepuluh) tahun dan denda paling banyak Rp. 5.000.000.000,00 (lima milyar rupiah).
Mengangkut, menguasai, atau memiliki hasil hutan yang tidak dilengkapi surat keterangan sahnya hasil hutan

\section{Pasal 50 ayat (3) huruf $h$}

Setiap orang dilarang mengangkut, menguasai, atau memiliki hasil hutan yang tidak dilengkapi bersama-sama dengan surat keterangan sahnya hasil hutan;

\section{Pasal 78 ayat (7)}

Barang siapa dengan sengaja melanggar ketentuan sebagaimana dimaksud dalam Pasal 50 ayat (3) huruf $\mathrm{h}$, diancam dengan pidana penjara paling lama 5 (lima) tahun dan denda paling banyak Rp. 10.000.000.000,00 (sepuluh milyar rupiah).

Menggembalakan
ternak di dalam
kawasan hutan
yang tidak ditunjuk
untuk maksud
tersebut

Menggembalakan ternak di dalam kawasan hutan tersebut

\section{Pasal 50 ayat (3) huruf $\mathrm{i}$}

Setiap orang dilarang menggembalakan ternak di dalam kawasan hutan yang tidak ditunjuk secara khusus untuk maksud tersebut oleh pejabat yang berwenang;

\section{Pasal 78 ayat (8)}

Barang siapa yang melanggar ketentuan sebagaimana dimaksud dalam Pasal 50 ayat (3) huruf i, diancam dengan pidana penjara paling lama 3 (tiga) bulan dan denda paling banyak Rp. 10.000.000,00 (sepuluh juta rupiah). 
Membawa alatalat berat dan atau alat-alat lainnya yang akan digunakan untuk mengangkut hasil hutan di dalam kawasan hutan tanpa izin

\section{Pasal $\mathbf{5 0}$ ayat (3) huruf $\mathbf{j}$}

Setiap orang dilarang membawa alat-alat berat dan atau alat-alat lainnya yang lazim atau patut diduga akan digunakan untuk mengangkut hasil hutan di dalam kawasan hutan, tanpa izin pejabat yang berwenang;

\section{Pasal 78 ayat (9)}

Barang siapa dengan sengaja melanggar ketentuan sebagaimana dimaksud dalam Pasal 50 ayat (3) huruf j, diancam dengan pidana penjara paling lama 5 (lima) tahun dan denda paling banyak Rp. 5.000.000.000,00 (lima milyar rupiah).
Membawa alatalat yang lazim digunakan untuk menebang, memotong, atau membelah pohon tanpa izin

\section{Pasal 50 ayat (3) huruf $k$}

Setiap orang dilarang membawa alat-alat yang lazim digunakan untuk menebang, memotong, atau membelah pohon di dalam kawasan hutan tanpa izin pejabat yang berwenang;

\section{Pasal 78 ayat (10)}

Barang siapa dengan sengaja melanggar ketentuan sebagaimana dimaksud dalam Pasal 50 ayat (3) huruf k, diancam dengan pidana penjara paling lama 3 (tiga) tahun dan denda paling banyak Rp. 1.000.000.000,00 (satu milyar rupiah).
Membuang bendabenda yang dapat menyebabkan kebakaran dan kerusakan serta membahayakan keberadaan atau kelangsungan fungsi hutan

\section{Pasal 50 ayat (3) huruf I}

Setiap orang dilarang membuang benda-benda yang dapat menyebabkan kebakaran dan kerusakan serta membahayakan keberadaan atau kelangsungan fungsi hutan ke dalam kawasan hutan;

\section{Pasal 78 ayat (11)}

Barang siapa dengan sengaja melanggar ketentuan sebagaimana dimaksud dalam Pasal 50 ayat (3) huruf i, diancam dengan pidana penjara paling lama 3 (tiga) tahun dan denda paling banyak Rp. 1.000.000.000,00 (satu milyar rupiah). 
Mengeluarkan, membawa, dan mengangkut tumbuh-tumbuhan dan satwa liar yang tidak dilindungi undang-undang yang berasal dari kawasan hutan tanpa izin

\section{Pasal $\mathbf{5 0}$ ayat (3) huruf $\mathrm{m}$}

Setiap orang dilarang mengeluarkan, membawa, dan mengangkut tumbuh-tumbuhan dan satwa liar yang tidak dilindungi undang-undang yang berasal dari kawasan hutan tanpa izin dari pejabat yang berwenang.

\section{Pasal 78 ayat (12)}

Barang siapa dengan sengaja melanggar ketentuan sebagaimana dimaksud dalam Pasal 50 ayat (3) huruf $\mathrm{m}$, diancam dengan pidana penjara paling lama 1 (satu) tahun dan denda paling banyak Rp. 50.000.000,00 (lima puluh juta rupiah).

\section{Kejahatan dan pelanggaran}

\section{Pasal 78 ayat (13)}

Tindak pidana sebagaimana dimaksud pada pasal 78 ayat (1), ayat (2), ayat (3), ayat (4), ayat (5), ayat (6), ayat (7), ayat (9), ayat (10), dan ayat (11) adalah kejahatan, dan tindak pidana sebagaimana dimaksud pada pasal 78 ayat (8) dan ayat (12) adalah pelanggaran. 


\section{Lampiran 5}

\section{Bentuk-bentuk Tindak \\ Pidana Korupsi dan Ancaman Pidananya}

Sesuai Undang-Undang Nomor 31 Tahun 1999 Sebagaimana Telah Diperbarui dengan UndangUndang Nomor 20 Tahun 2001 tentang Pemberantasan Tindak Pidana Korupsi

Sumber: http://www.kpk.go.id/uploads/doks/uu/UU202001.pdf dan http://www.kpk.go.id/ uploads/doks/uu/UU311999.pdf

\begin{tabular}{ll}
\hline & Pasal 2 ayat (1) \\
\hline $\begin{array}{l}\text { Melawan hukum } \\
\text { diri dan dapat } \\
\text { merugikan } \\
\text { keuangan negara }\end{array}$ & $\begin{array}{l}\text { Setiap orang yang secara melawan hukum melakukan } \\
\text { perbuatan memperkaya diri sendiri atau orang lain } \\
\text { atau suatu korporasi yang dapat merugikan keuangan } \\
\text { negara atau perekonomian negara. }\end{array}$ \\
& $\begin{array}{l}\text { Dipidana penjara dengan penjara seumur hidup atau } \\
\text { pidana penjara paling singkat 4 (empat) tahun dan } \\
\text { paling lama 20 (dua puluh) tahun dan denda paling } \\
\text { sedikit Rp. 200.000.000,00 (dua ratus juta rupiah) dan } \\
\text { paling banyak Rp. 1.000.000.000,00 (satu milyar rupiah). }\end{array}$ \\
& Pasal 2 ayat (2) \\
& $\begin{array}{l}\text { Dalam hal tindak pidana korupsi sebagaimana } \\
\text { dimaksud dalam Pasal } 2 \text { ayat (1) dilakukan dalam } \\
\text { keadaan tertentu, pidana mati dapat dijatuhkan. }\end{array}$ \\
\hline
\end{tabular}


Yang dimaksud dengan "keadaan tertentu" adalah keadaan yang dapat dijadikan alasan pemberatan pidana bagi pelaku tindak pidana korupsi yaitu apabila tindak pidana tersebut dilakukan terhadap dana-dana yang diperuntukkan bagi penanggulangan keadaan bahaya, bencana alam nasional, penanggulangan akibat kerusuhan sosial yang meluas, penanggulangan krisis ekonomi dan moneter, dan pengulangan tindak pidana korupsi.

\section{Pasal 3}

Menyalahgunakan kewenangan untuk menguntungkan diri dan dapat merugikan keuangan negara
Setiap orang yang dengan tujuan menguntungkan diri sendiri atau orang lain atau suatu korporasi, menyalahgunakan kewenangan, kesempatan atau sarana yang ada padanya karena jabatan atau kedudukan yang dapat merugikan keuangan negara atau perekonomian negara.

Dipidana dengan pidana penjara seumur hidup atau pidana penjara paling singkat 1 (satu) tahun dan paling lama 20 (dua puluh) tahun dan atau denda paling sedikit Rp. 50.000.000,00 (lima puluh juta rupiah) dan paling banyak Rp. 1.000.000.000,00 (satu milyar rupiah).

\section{Pasal 5 ayat (1) huruf a}

\section{Menyuap pegawai negeri}

Setiap orang yang memberi atau menjanjikan sesuatu kepada pegawai negeri atau penyelenggara negara dengan maksud supaya pegawai negeri atau penyelenggara negara tersebut berbuat atau tidak berbuat sesuatu dalam jabatannya yang bertentangan dengan kewajibannya.

Dipidana dengan pidana penjara paling singkat 1 (satu) tahun dan paling lama 5 (lima) tahun dan atau pidana denda paling sedikit Rp 50.000.000,00 (lima puluh juta rupiah) dan paling banyak Rp 250.000.000,00 (dua ratus lima puluh juta rupiah). 


\section{Pasal 5 ayat (1) huruf b}

\begin{tabular}{ll}
\hline Menyuap pegawai & Setiap orang yang memberi sesuatu kepada pegawai \\
negeri & negeri atau penyelenggara negara karena atau \\
berhubungan dengan sesuatu yang bertentangan & dengan kewajiban, dilakukan atau tidak dilakukan \\
& dalam jabatannya. \\
& Dipidana dengan pidana penjara paling singkat 1 (satu) \\
& tahun dan paling lama 5 (lima) tahun dan atau pidana \\
& denda paling sedikit Rp 50.000.000,00 (lima puluh juta \\
& rupiah) dan paling banyak Rp 250.000.000,00 (dua ratus \\
lima puluh juta rupiah).
\end{tabular}

\section{Pasal 5 ayat (2)}

\section{Pegawai negeri menerima suap}

Bagi pegawai negeri atau penyelenggara negara yang menerima pemberian atau janji sebagaimana dimaksud dalam Pasal 5 ayat (1) huruf a atau huruf b, dipidana dengan pidana yang sama sebagaimana dimaksud dalam Pasal 5 ayat (1).

\section{Pasal 6 ayat (1) huruf a}

\section{Menyuap hakim}

Setiap orang yang memberi atau menjanjikan sesuatu kepada hakim dengan maksud untuk mempengaruhi putusan perkara yang diserahkan kepadanya untuk diadili.

Dipidana dengan pidana penjara paling singkat 3 (tiga) tahun dan paling lama 15 (lima belas) tahun dan pidana denda paling sedikit Rp 150.000.000,00 (seratus lima puluh juta rupiah) dan paling banyak Rp 750.000.000,00 (tujuh ratus lima puluh juta rupiah).

\section{Pasal 6 ayat (1) huruf b}

\section{Menyuap advokat}

Setiap orang yang memberi atau menjanjikan sesuatu kepada seseorang yang menurut ketentuan peraturan perundang-undangan ditentukan menjadi advokat untuk menghadiri sidang pengadilan dengan maksud untuk mempengaruhi nasihat atau pendapat yang akan diberikan berhubung dengan perkara yang diserahkan kepada pengadilan untuk diadili. 
Dipidana dengan pidana penjara paling singkat 3 (tiga) tahun dan paling lama 15 (lima belas) tahun dan pidana denda paling sedikit Rp 150.000.000,00 (seratus lima puluh juta rupiah) dan paling banyak Rp 750.000.000,00 (tujuh ratus lima puluh juta rupiah).

\section{Pasal 6 ayat (2)}

Hakim dan advokat menerima suap
Bagi hakim yang menerima pemberian atau janji sebagaimana dimaksud dalam Pasal 6 ayat (1) huruf a atau advokat yang menerima pemberian atau janji sebagaimana dimaksud dalam Pasal 6 ayat (1) huruf b, dipidana dengan pidana yang sama sebagaimana dimaksud dalam Pasal 6 ayat (1).

\section{Pasal 7 ayat (1) huruf a}

\section{Pemborong} berbuat curang
Pemborong, ahli bangunan yang pada waktu membuat bangunan, atau penjual bahan bangunan yang pada waktu menyerahkan bahan bangunan, melakukan perbuatan curang yang dapat membahayakan keamanan orang atau barang, atau keselamatan negara dalam keadaan perang;

Dipidana dengan pidana penjara paling singkat 2 (dua) tahun dan paling lama 7 (tujuh) tahun dan atau pidana denda paling sedikit Rp 100.000.000,00 (seratus juta rupiah) dan paling banyak Rp 350.000.000,00 (tiga ratus lima puluh juta rupiah).

\section{Pasal 7 ayat (1) huruf b}

Pengawas Proyek membiarkan perbuatan curang
Setiap orang yang bertugas mengawasi pembangunan atau penyerahan bahan bangunan, sengaja membiarkan perbuatan curang sebagaimana dimaksud dalam huruf a;

Dipidana dengan pidana penjara paling singkat 2 (dua) tahun dan paling lama 7 (tujuh) tahun dan atau pidana denda paling sedikit Rp 100.000.000,00 (seratus juta rupiah) dan paling banyak Rp 350.000.000,00 (tiga ratus lima puluh juta rupiah). 


\section{Pasal 7 ayat (1) huruf c}

\section{Rekanan TNI/Polri berbuat curang}

Setiap orang yang pada waktu menyerahkan barang keperluan Tentara Nasional Indonesia dan atau Kepolisian Negara Republik Indonesia melakukan perbuatan curang yang dapat membahayakan keselamatan negara dalam keadaan perang.

Dipidana dengan pidana penjara paling singkat 2 (dua) tahun dan paling lama 7 (tujuh) tahun dan atau pidana denda paling sedikit Rp 100.000.000,00 (seratus juta rupiah) dan paling banyak Rp 350.000.000,00 (tiga ratus lima puluh juta rupiah).

\section{Pasal 7 ayat (1) huruf $d$}

\section{Pengawas rekanan TNI/Polri berbuat curang}

Setiap orang yang bertugas mengawasi penyerahan barang keperluan Tentara Nasional Indonesia dan atau Kepolisian Negara Republik Indonesia dengan sengaja membiarkan perbuatan curang sebagaimana dimaksud dalam Pasal 7 ayat (1) huruf c.

Dipidana dengan pidana penjara paling singkat 2 (dua) tahun dan paling lama 7 (tujuh) tahun dan atau pidana denda paling sedikit Rp 100.000.000,00 (seratus juta rupiah) dan paling banyak Rp 350.000.000,00 (tiga ratus lima puluh juta rupiah).

\section{Pasal 7 ayat (2)}

\section{Penerima \\ barang TNI/Polri membiarkan perbuatan curang}

Bagi orang yang menerima penyerahan bahan bangunan atau orang yang menerima penyerahan barang keperluan Tentara Nasional Indonesia dan atau Kepolisian Negara Republik Indonesia dan membiarkan perbuatan curang sebagaimana dimaksud dalam pasal 7 ayat (1) huruf a atau huruf c, dipidana dengan pidana yang sama sebagaimana dimaksud dalam ayat pasal 7 ayat (1). 


\section{Pasal 8}

Pegawai negeri menggelapkan uang atau membiarkan penggelapan
Pegawai negeri atau orang selain pegawai negeri yang ditugaskan menjalankan suatu jabatan umum secara terus menerus atau untuk sementara waktu, dengan sengaja menggelapkan uang atau surat berharga yang disimpan karena jabatannya, atau membiarkan uang atau surat berharga tersebut diambil atau digelapkan oleh orang lain, atau membantu dalam melakukan perbuatan tersebut.

Dipidana dengan pidana penjara paling singkat 3 (tiga) tahun dan paling lama 15 (lima belas) tahun dan pidana denda paling sedikit Rp 150.000.000,00 (seratus lima puluh juta rupiah) dan paling banyak Rp 750.000.000,00 (tujuh ratus lima puluh juta rupiah).

\section{Pasal 9}

Pegawai negeri memalsukan buku untuk pemeriksaan administratif
Pegawai negeri atau orang selain pegawai negeri yang diberi tugas menjalankan suatu jabatan umum secara terus menerus atau untuk sementara waktu, dengan sengaja memalsukan buku-buku atau daftar-daftar yang khusus untuk pemeriksaan administrasi.

Dipidana dengan pidana penjara paling singkat 1 (satu) tahun dan paling lama 5 (lima) tahun dan pidana denda paling sedikit Rp 50.000.000,00 (lima puluh juta rupiah) dan paling banyak Rp 250.000.000,00 (dua ratus lima puluh juta rupiah).

\section{Pasal 10 huruf a}

\section{Pegawai negeri} merusakkan bukti
Pegawai negeri atau orang selain pegawai negeri yang diberi tugas menjalankan suatu jabatan umum secara terus menerus atau untuk sementara waktu, dengan sengaja menggelapkan, menghancurkan, merusakkan, atau membuat tidak dapat dipakai barang, akta, surat, atau daftar yang digunakan untuk meyakinkan atau membuktikan di muka pejabat yang berwenang yang dikuasai karena jabatannya.

Dipidana dengan pidana penjara paling singkat 2 (dua) tahun dan paling lama 7 (tujuh) tahun dan pidana denda paling sedikit Rp 100.000.000,00 (seratus juta rupiah) dan paling banyak Rp 350.000.000,00 (tiga ratus lima puluh juta rupiah). 


\section{Pasal 10 huruf $b$}

Pegawai negeri
membiarkan orang
lain merusakkan
bukti

Pegawai negeri lain merusakkan bukti
Pegawai negeri atau orang selain pegawai negeri yang diberi tugas menjalankan suatu jabatan umum secara terus menerus atau untuk sementara waktu, dengan sengaja membiarkan orang lain menghilangkan, menghancurkan, merusakkan, atau membuat tidak dapat dipakai barang, akta, surat, atau daftar tersebut.

Dipidana dengan pidana penjara paling singkat 2 (dua) tahun dan paling lama 7 (tujuh) tahun dan pidana denda paling sedikit Rp 100.000.000,00 (seratus juta rupiah) dan paling banyak Rp 350.000.000,00 (tiga ratus lima puluh juta rupiah).

\section{Pasal 10 huruf c}

\section{Pegawai negeri membantu orang lain merusakkan bukti}

Pegawai negeri atau orang selain pegawai negeri yang diberi tugas menjalankan suatu jabatan umum secara terus menerus atau untuk sementara waktu, dengan sengaja membantu orang lain menghilangkan, menghancurkan, merusakkan, atau membuat tidak dapat dipakai barang, akta, surat, atau daftar tersebut.

Dipidana dengan pidana penjara paling singkat 2 (dua) tahun dan paling lama 7 (tujuh) tahun dan pidana denda paling sedikit Rp 100.000.000,00 (seratus juta rupiah) dan paling banyak $\mathrm{Rp}$ 350.000.000,00 (tiga ratus lima puluh juta rupiah).

\section{Pasal 11}

Pegawai negeri menerima hadiah yang berhubungan dengan jabatannya
Pegawai negeri atau penyelenggara negara yang menerima hadiah atau janji padahal diketahui atau patut diduga, bahwa hadiah atau janji tersebut diberikan karena kekuasaan atau kewenangan yang berhubungan dengan jabatannya, atau yang menurut pikiran orang yang memberikan hadiah atau janji tersebut ada hubungan dengan jabatannya.

Dipidana dengan pidana penjara paling singkat 1 (satu) tahun dan paling lama 5 (lima) tahun dan atau pidana denda paling sedikit Rp 50.000.000,00 (lima puluh juta rupiah) dan paling banyak Rp 250.000.000,00 (dua ratus lima puluh juta rupiah). 


\section{Pasal 12 huruf a}

\section{Pegawai negeri} menerima suap
Pegawai negeri atau penyelenggara negara yang menerima hadiah atau janji, padahal diketahui atau patut diduga bahwa hadiah atau janji tersebut diberikan untuk menggerakkan agar melakukan atau tidak melakukan sesuatu dalam jabatannya yang bertentangan dengan kewajibannya.

Dipidana dengan pidana penjara seumur hidup atau pidana penjara paling singkat 4 (empat) tahun dan paling lama 20 (dua puluh) tahun dan pidana denda paling sedikit Rp 200.000.000,00 (dua ratus juta rupiah) dan paling banyak Rp 1.000.000.000,00 (satu miliar rupiah).

\section{Pasal 12 huruf $b$}

\section{Pegawai negeri} menerima suap
Pegawai negeri atau penyelenggara negara yang menerima hadiah, padahal diketahui atau patut diduga bahwa hadiah tersebut diberikan sebagai akibat atau disebabkan karena telah melakukan atau tidak melakukan sesuatu dalam jabatannya yang bertentangan dengan kewajibannya;

Dipidana dengan pidana penjara seumur hidup atau pidana penjara paling singkat 4 (empat) tahun dan paling lama 20 (dua puluh) tahun dan pidana denda paling sedikit Rp 200.000.000,00 (dua ratus juta rupiah) dan paling banyak Rp 1.000.000.000,00 (satu miliar rupiah).

\section{Pasal 12 huruf c}

\section{Hakim menerima suap}

Hakim yang menerima hadiah atau janji, padahal diketahui atau patut diduga bahwa hadiah atau janji tersebut diberikan untuk mempengaruhi putusan perkara yang diserahkan kepadanya untuk diadili

Dipidana dengan pidana penjara seumur hidup atau pidana penjara paling singkat 4 (empat) tahun dan paling lama 20 (dua puluh) tahun dan pidana denda paling sedikit Rp 200.000.000,00 (dua ratus juta rupiah) dan paling banyak Rp 1.000.000.000,00 (satu miliar rupiah). 


\section{Pasal 12 huruf d}

Advokat menerima
suap

Advokat menerima suap
Seseorang yang menurut ketentuan peraturan perundang-undangan ditentukan menjadi advokat untuk menghadiri sidang pengadilan, menerima hadiah atau janji, padahal diketahui atau patut diduga bahwa hadiah atau janji tersebut untuk mempengaruhi nasihat atau pendapat yang akan diberikan, berhubung dengan perkara yang diserahkan kepada pengadilan untuk diadili.

Dipidana dengan pidana penjara seumur hidup atau pidana penjara paling singkat 4 (empat) tahun dan paling lama 20 (dua puluh) tahun dan pidana denda paling sedikit Rp 200.000.000,00 (dua ratus juta rupiah) dan paling banyak Rp 1.000.000.000,00 (satu miliar rupiah).

\section{Pasal 12 huruf e}

Pegawai negeri memeras
Pegawai negeri atau penyelenggara negara yang dengan maksud menguntungkan diri sendiri atau orang lain secara melawan hukum, atau dengan menyalahgunakan kekuasaannya memaksa seseorang memberikan sesuatu, membayar, atau menerima pembayaran dengan potongan, atau untuk mengerjakan sesuatu bagi dirinya sendiri.

Dipidana dengan pidana penjara seumur hidup atau pidana penjara paling singkat 4 (empat) tahun dan paling lama 20 (dua puluh) tahun dan pidana denda paling sedikit Rp 200.000.000,00 (dua ratus juta rupiah) dan paling banyak Rp 1.000.000.000,00 (satu miliar rupiah).

\section{Pasal 12 huruf $f$}

Pegawai negeri memeras pegawai negeri yang lain
Pegawai negeri atau penyelenggara negara yang pada waktu menjalankan tugas, meminta, menerima, atau memotong pembayaran kepada pegawai negeri atau penyelenggara negara yang lain atau kepada kas umum, seolah-olah pegawai negeri atau penyelenggara negara yang lain atau kas umum tersebut mempunyai utang kepadanya, padahal diketahui bahwa hal tersebut bukan merupakan utang. 
Dipidana dengan pidana penjara seumur hidup atau pidana penjara paling singkat 4 (empat) tahun dan paling lama 20 (dua puluh) tahun dan pidana denda paling sedikit Rp 200.000.000,00 (dua ratus juta rupiah) dan paling banyak Rp 1.000.000.000,00 (satu miliar rupiah).

\section{Pasal 12 huruf $g$}

\section{Pegawai negeri memeras}

Pegawai negeri atau penyelenggara negara yang pada waktu menjalankan tugas, meminta atau menerima pekerjaan, atau penyerahan barang, seolah-olah merupakan utang kepada dirinya, padahal diketahui bahwa hal tersebut bukan merupakan utang.

Dipidana dengan pidana penjara seumur hidup atau pidana penjara paling singkat 4 (empat) tahun dan paling lama 20 (dua puluh) tahun dan pidana denda paling sedikit Rp 200.000.000,00 (dua ratus juta rupiah) dan paling banyak Rp 1.000.000.000,00 (satu miliar rupiah).

\section{Pasal 12 huruf $h$}

Pegawai negeri menyerobot tanah negara sehingga merugikan orang lain
Pegawai negeri atau penyelenggara negara yang pada waktu menjalankan tugas, telah menggunakan tanah negara yang di atasnya terdapat hak pakai, seolah-olah sesuai dengan peraturan perundang-undangan, telah merugikan orang yang berhak, padahal diketahuinya bahwa perbuatan tersebut bertentangan dengan peraturan perundang-undangan;

Dipidana dengan pidana penjara seumur hidup atau pidana penjara paling singkat 4 (empat) tahun dan paling lama 20 (dua puluh) tahun dan pidana denda paling sedikit Rp 200.000.000,00 (dua ratus juta rupiah) dan paling banyak Rp 1.000.000.000,00 (satu miliar rupiah).

\section{Pasal 12 huruf $i$}

Pegawai negeri turut serta dalam pengadaan yang diurusnya
Pegawai negeri atau penyelenggara negara baik langsung maupun tidak langsung dengan sengaja turut serta dalam pemborongan, pengadaan, atau persewaan, yang pada saat dilakukan perbuatan, untuk seluruh atau sebagian ditugaskan untuk mengurus atau mengawasinya. 


\begin{tabular}{|c|c|}
\hline & $\begin{array}{l}\text { Dipidana dengan pidana penjara seumur hidup } \\
\text { atau pidana penjara paling singkat } 4 \text { (empat) tahun } \\
\text { dan paling lama } 20 \text { (dua puluh) tahun dan pidana } \\
\text { denda paling sedikit Rp 200.000.000,00 (dua ratus juta } \\
\text { rupiah) dan paling banyak Rp 1.000.000.000,00 (satu } \\
\text { miliar rupiah). }\end{array}$ \\
\hline & Pasal $12 \mathrm{~A}$ ayat (1) \\
\hline & $\begin{array}{l}\text { Ketentuan mengenai pidana penjara dan pidana } \\
\text { denda sebagaimana dimaksud dalam Pasal 5, Pasal 6, } \\
\text { Pasal 7, Pasal 8, Pasal 9, Pasal 10, Pasal } 11 \text { dan Pasal } 12 \\
\text { tidak berlaku bagi tindak pidana korupsi yang nilainya } \\
\text { kurang dari Rp 5.000.000,00 (lima juta rupiah). }\end{array}$ \\
\hline & Pasal $12 \mathrm{~A}$ ayat (2) \\
\hline & $\begin{array}{l}\text { Bagi pelaku tindak pidana korupsi yang nilainya kurang } \\
\text { dari Rp 5.000.000,00 (lima juta rupiah) sebagaimana } \\
\text { dimaksud dalam Pasal } 12 \text { ayat (1) dipidana dengan } \\
\text { pidana penjara paling lama } 3 \text { (tiga) tahun dan pidana } \\
\text { denda paling banyak Rp 50.000.000,00 (lima puluh } \\
\text { juta rupiah). }\end{array}$ \\
\hline & Pasal 12 B ayat (1) \\
\hline $\begin{array}{l}\text { Pegawai negeri } \\
\text { menerima } \\
\text { gratifikasi dan tidak } \\
\text { lapor KPK }\end{array}$ & $\begin{array}{l}\text { Setiap gratifikasi kepada pegawai negeri atau } \\
\text { penyelenggara negara dianggap pemberian suap, } \\
\text { apabila berhubungan dengan jabatannya dan yang } \\
\text { berlawanan dengan kewajiban atau tugasnya, dengan } \\
\text { ketentuan sebagai berikut: } \\
\text { a. yang nilainya Rp 10.000.000,00 (sepuluh juta } \\
\text { rupiah) atau lebih, pembuktian bahwa gratifikasi } \\
\text { tersebut bukan merupakan suap dilakukan oleh } \\
\text { penerima gratifikasi; } \\
\text { b. yang nilainya kurang dari Rp 10.000.000,00 } \\
\text { (sepuluh juta rupiah), pembuktian bahwa gratifikasi } \\
\text { tersebut suap dilakukan oleh penuntut umum. }\end{array}$ \\
\hline
\end{tabular}




\section{Pasal 12 B ayat (2)}

Pidana bagi pegawai negeri atau penyelenggara negara sebagaimana dimaksud dalam pasal 12 B ayat (1) adalah pidana penjara seumur hidup atau pidana penjara paling singkat 4 (empat) tahun dan paling lama 20 (dua puluh) tahun, dan pidana denda paling sedikit Rp 200.000.000,00 (dua ratus juta rupiah) dan paling banyak Rp 1.000.000.000,00 (satu miliar rupiah).

\section{Pasal $12 \mathrm{C}$}

(1) Ketentuan sebagaimana dimaksud dalam Pasal 12 B ayat (1) tidak berlaku, jika penerima melaporkan gratifikasi yang diterimanya kepada Komisi Pemberantasan Tindak Pidana Korupsi.

(2) Penyampaian laporan sebagaimana dimaksud dalam ayat (1) wajib dilakukan oleh penerima gratifikasi paling lambat 30 (tiga puluh) hari kerja terhitung sejak tanggal gratifikasi tersebut diterima.

(3) Komisi Pemberantasan Tindak Pidana Korupsi dalam waktu paling lambat 30 (tiga puluh) hari kerja sejak tanggal menerima laporan wajib menetapkan gratifikasi dapat menjadi milik penerima atau milik negara.

(4) Ketentuan mengenai tata cara penyampaian laporan sebagaimana dimaksud dalam ayat (2) dan penentuan status gratifikasi sebagaimana dimaksud dalam ayat (3) diatur dalam Undangundang tentang Komisi Pemberantasan Tindak Pidana Korupsi.

\section{Pasal 13}

\section{Memberi hadiah kepada pegawai negeri karena jabatannya}

Setiap orang yang memberi hadiah atau janji kepada pegawai negeri dengan mengingat kekuasaan atau wewenang yang melekat pada jabatan atau kedudukannya, atau oleh pemberi hadiah atau janji dianggap melekat pada jabatan atau kedudukan tersebut.

Dipidana dengan pidana penjara paling lama 3 (tiga) tahun dan atau denda paling banyak 150.000.000,00 (seratus lima puluh juta rupiah). 


\section{Pasal 14}

\begin{tabular}{ll}
\hline $\begin{array}{l}\text { Melanggar } \\
\text { ketentuan tindak } \\
\text { pidana korupsi di } \\
\begin{array}{l}\text { Undang-Undang } \\
\text { lain }\end{array}\end{array}$ & $\begin{array}{l}\text { Setiap orang yang melanggar ketentuan Undang- } \\
\text { undang yang secara tegas menyatakan bahwa } \\
\text { pelanggaran terhadap ketentuan Undang-undang } \\
\text { tersebut sebagai tindak pidana korupsi berlaku } \\
\text { ketentuan yang diatur dalam Undang-undang ini. }\end{array}$ \\
\hline & Pasal 15 \\
\hline $\begin{array}{l}\text { Percobaan, } \\
\text { perbantuan, atau } \\
\text { pemufakatan jahat } \\
\text { untuk melakukan } \\
\text { tindak pidana } \\
\text { korupsi }\end{array}$ & $\begin{array}{l}\text { Setiap orang yang melakukan percobaan, pembantuan, } \\
\text { atau pemufakatan jahat untuk melakukan tindak } \\
\text { sebagaimana dimaksud Pasal 2, Pasal 3, Pasal 5 sampai } \\
\text { dengan Pasal 14. }\end{array}$ \\
\hline
\end{tabular}

\section{Pasal 16}

Memberikan

bantuan, kesempatan, sarana, atau keterangan untuk terjadi tindak pidana korupsi dari luar negeri
Setiap orang di luar wilayah negara Republik Indonesia yang memberikan bantuan, kesempatan, sarana, atau keterangan untuk terjadi tindak pidana korupsi dipidana dengan pidana yang sama sebagai pelaku tindak pidana korupsi sebagaimana dimaksud dalam Pasal 2, Pasal 3, Pasal 5 sampai dengan Pasal 14.

\section{Pasal 17}

Pidana tambahan Selain dapat dijatuhi pidana sebagaimana dimaksud dalam Pasal 2, Pasal 3, Pasal 5 sampai dengan Pasal 14, terdakwa dapat dijatuhi pidana tambahan sebagaimana dimaksud dalam Pasal 18. 


\section{Pasal 18 ayat (1)}

Pidana tambahan
Selain pidana tambahan sebagaimana dimaksud dalam Kitab Undang-Undang Hukum Pidana, sebagai pidana tambahan adalah:

a. Perampasan barang bergerak yang berwujud atau yang tidak berwujud atau barang tidak bergerak yang digunakan untuk atau yang diperoleh dari tindak pidana korupsi, termasuk perusahaan milik terpidana di mana tindak pidana korupsi dilakukan, begitu pula dari barang yang menggantikan barang-barang tersebut;

b. Pembayaran uang pengganti yang jumlahnya sebanyak-banyaknya sama dengan harta benda yang diperoleh dari tindak pidana korupsi;

c. Penutupan seluruh atau sebagian perusahaan untuk waktu paling lama 1 (satu) tahun;

d. Pencabutan seluruh atau sebagian hak-hak tertentu atau penghapusan seluruh atau sebagian keuntungan tertentu, yang telah atau dapat diberikan oleh Pemerintah kepada terpidana.

\section{Pasal 18 ayat (2)}

Terpidana yang tidak membayar uang pengganti
Jika terpidana tidak membayar uang pengganti sebagaimana dimaksud dalam Pasal 18 ayat (1) huruf b paling lama dalam waktu 1 (satu) bulan sesudah putusan pengadilan yang telah memperoleh kekuatan hukum tetap, maka harta bendanya dapat disita oleh jaksa dan dilelang untuk menutupi uang pengganti tersebut.

\section{Pasal 18 ayat (3)}

Terpidana yang harta bendanya tidak cukup untuk membayar uang pengganti jika dalam hal terpidana tidak mempunyai harta benda yang mencukupi untuk membayar uang pengganti sebagaimana dimaksud dalam Pasal 18 ayat (1) huruf b, maka dipidana dengan pidana penjara yang lamanya tidak melebihi ancaman maksimum dari pidana pokoknya sesuai dengan ketentuan dalam Undangundang ini dan lamanya pidana tersebut sudah ditentukan dalam putusan pengadilan. 


\section{Lampiran 6}

\section{Hasil Tindak Pidana dan Bentuk-bentuk Tindak Pidana Pencucian Uang dan Ancaman Pidananya}

Sesuai Undang-Undang Nomor 8 Tahun 2010 tentang Pencegahan dan Pemberantasan Tindak Pidana Pencucian Uang

Pasal 2 ayat 1

$\begin{array}{ll}\text { Kategorisasi hasil- } & \text { Hasil tindak pidana adalah Harta Kekayaan yang } \\ \text { hasil tindak pidana } & \text { diperoleh dari tindak pidana: } \\ \text { yang merupakan } & \text { a. korupsi; } \\ \text { kejahatan asal } & \text { b. penyuapan; } \\ \text { pencucian uang } & \text { c. narkotika; } \\ & \text { d. psikotropika; } \\ & \text { e. penyelundupan tenaga kerja; } \\ & \text { f. penyelundupan migran; } \\ \text { g. di bidang perbankan; } & \text { h. di bidang pasar modal; } \\ \text { i. di bidang perasuransian; } \\ \text { j. kepabeanan; } \\ \text { k. cukai; } \\ \text { l. perdagangan orang; } \\ \text { m. perdagangan senjata gelap; } \\ \text { n. terorisme; } \\ \text { o. penculikan; } \\ \text { p. pencurian; } \\ \text { q. penggelapan; } \\ \text { r. penipuan; }\end{array}$


S. pemalsuan uang;

t. perjudian;

u. prostitusi;

v. di bidang perpajakan;

w. di bidang kehutanan;

x. di bidang lingkungan hidup

y. di bidang kelautan dan perikanan; atau

z. tindak pidana lain yang diancam dengan pidana penjara 4 (empat) tahun atau lebih, yang dilakukan di wilayah Negara Kesatuan Republik Indonesia atau di luar wilayah Negara Kesatuan Republik Indonesia dan tindak pidana tersebut juga merupakan tindak pidana menurut hukum Indonesia.

\section{Pasal 3}

\section{Secara aktif melakukan tindak pidana pencucian uang}

Setiap orang yang menempatkan, mentransfer, mengalihkan, membelanjakan, membayarkan, menghibahkan, menitipkan, membawa ke luar negeri, mengubah bentuk, menukarkan dengan mata uang atau surat berharga atau perbuatan lain atas Harta Kekayaan yang diketahuinya atau patut diduganya merupakan hasil tindak pidana sebagaimana dimaksud dalam Pasal 2 ayat (1) dengan tujuan menyembunyikan atau menyamarkan asal usul Harta Kekayaan.

Dipidana karena tindak pidana pencucian uang dengan pidana penjara paling lama 20 (dua puluh) tahun dan denda paling banyak Rp10.000.000.000,00 (sepuluh miliar rupiah).

\section{Pasal 4}

Setiap orang yang menyembunyikan atau menyamarkan asal usul, sumber, lokasi, peruntukan, pengalihan hak-hak, atau kepemilikan yang sebenarnya atas Harta Kekayaan yang diketahuinya atau patut diduganya merupakan hasil tindak pidana sebagaimana dimaksud dalam Pasal 2 ayat (1).

Dipidana karena tindak pidana pencucian uang dengan pidana penjara paling lama 20 (dua puluh) tahun dan denda paling banyak Rp5.000.000.000,00 (lima miliar rupiah). 


\section{Pasal 5 ayat 1}

\section{Secara pasif \\ melakukan tindak pidana pencucian uang}

Orang yang menerima atau menguasai pentransferan, pembayaran, hibah, sumbangan, penitipan, penukaran, atau menggunakan Harta Kekayaan yang diketahuinya atau patut diduganya merupakan hasil tindak pidana sebagaimana dimaksud dalam Pasal 2 ayat (1).

Dipidana dengan pidana penjara paling lama 5 (lima) tahun dan denda paling banyak Rp1.000.000.000,00 (satu miliar rupiah).

\section{Pasal 6}

$\begin{array}{ll}\text { Korporasi/personil } & \text { (1) Dalam hal tindak pidana pencucian uang } \\ \text { korporasi yang } & \text { sebagaimana dimaksud dalam Pasal 3, Pasal 4, dan Pasal } \\ \text { melakukan tindak } & 5 \text { dilakukan oleh Korporasi, pidana dijatuhkan terhadap } \\ \text { pidana pencucian } & \text { Korporasi dan/atau Personil Pengendali Korporasi. } \\ \text { uang } & \text { (2) Pidana dijatuhkan terhadap Korporasi apabila tindak } \\ & \text { pidana pencucian uang: } \\ \text { a. } \quad \text { dilakukan atau diperintahkan oleh Personil } & \text { Pengendali Korporasi; } \\ & \text { b. dilakukan dalam rangka pemenuhan maksud dan } \\ & \text { tujuan Korporasi; } \\ \text { c. } \text { dilakukan sesuai dengan tugas dan fungsi pelaku } \\ \text { atau pemberi perintah; dan } \\ \text { d. dilakukan dengan maksud memberikan manfaat } \\ \text { bagi Korporasi. }\end{array}$




\section{Pasal 7}

(1) Pidana pokok yang dijatuhkan terhadap Korporasi adalah pidana denda paling banyak Rp100.000.000.000,00 (seratus miliar rupiah).

(2) Selain pidana denda sebagaimana dimaksud pada ayat (1), terhadap Korporasi juga dapat dijatuhkan pidana tambahan berupa:

a. pengumuman putusan hakim;

b. pembekuan sebagian atau seluruh kegiatan usaha Korporasi;

c. pencabutan izin usaha;

d. pembubaran dan/atau pelarangan Korporasi;

e. perampasan aset Korporasi untuk negara; dan/atau

f. pengambilalihan Korporasi oleh negara

\section{Pasal 10}

Percobaan,

pembantuan, atau permufakatan jahat pencucian uang
Setiap Orang yang berada di dalam atau di luar wilayah Negara Kesatuan Republik Indonesia yang turut serta melakukan percobaan, pembantuan, atau Permufakatan Jahat untuk melakukan tindak pidana pencucian uang.

Dipidana dengan pidana yang sama sebagaimana dimaksud dalam Pasal 3, Pasal 4, dan Pasal 5. 


Panduan audit investigatif ini disusun sebagai bagian dari upaya untuk mendorong keterpaduan pada tingkatan teknis operasional dalam aspek pemberantasan korupsi, pencucian uang dan kejahatan kehutanan. Panduan ini disusun agar audit investigatif dapat dilaksanakan dengan baik dan hasilnya sesuai dengan kualifikasi yang dibutuhkan penyelidik dan penyidik untuk melaksanakan penyelidikan dan penyidikan korupsi, pencucian uang dan kejahatan dalam bidang kehutanan.

Panduan audit investigatif ini ditulis untuk memberikan pedoman kepada para Auditor, baik di lembaga pemerintahan maupun non-pemerintahan, untuk merencanakan, melaksanakan serta menyusun laporan audit investigatif dalam rangka mengungkapkan adanya korupsi, pencucian uang dan kejahatan yang berkaitan dengan bidang kehutanan.

\section{Center for International Forestry Research}

CIFOR memajukan kesejahteraan manusia, konservasi lingkungan dan kesetaraan melalui penelitian yang berorientasi pada kebijakan dan praktik kehutanan di negara berkembang. CIFOR merupakan salah satu dari 15 pusat penelitian dalam Kelompok Konsultatif bagi Penelitian Pertanian International (Consultative Group on International Agricultural Research - CGIAR). CIFOR berkantor pusat di Bogor, Indonesia dengan kantor wilayah di Asia, Afrika dan Amerika Selatan. 